\title{
Det civiliserede kaos
}

Maskerade-motivet iflg. Ludvig Holberg, Vilhelm
Andersen og Carl Nielsen

Festens metaforik

I 1704 - muligvis 1711, ${ }^{1}$ der er lidt usikkerhed om dateringen - skabte Benô̂t le Coffre loftmaleriet af en maskerade til dansesalen på Frederiksberg Slot.

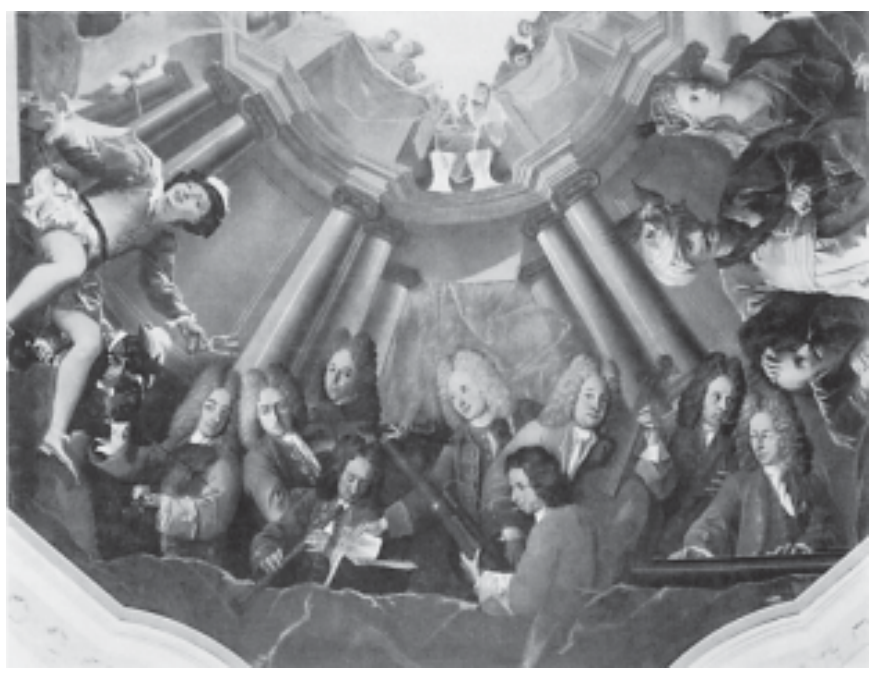

Detalje af le Coffres Maskeradebillede (jfr. omslagsillustration). Billedet er en vision som åbner sig opad mod en tom himmel, $u$ den noget samlende centrum eller symbol, det lader sig lase bogstavelig talt påflere niveauer, teater, musik, maske-

spil, erotik $i$ en samlet refleksion af tidens centrale frivolt-eksistentielle begreb om fest-og samtidig efter al sandsynlighed en afbildning af faktiske kunstnere i majestatens sold. Det anses for givet, at Frederik 4.s ni hofvioloner er portratteret, ${ }^{2}$ og ligeledes for sandsynligt, at medlemmer af Montaigus franske hofteatertrup figurerer. Vi har altså en tvetydighed, en dobbelthed i maleriet: en blanding af illusionsallegori-loftmaleriet er nosten pr. definition allegorisk - og dokumentarisk fête galante, narmest for genren blev opfundet. Samtidig reflekterer og fordobler det salens aktiviteter, haver sig over dem. I kraft af sin realisme er billedet ikke symbolsk, men selv et symbol. 
Le Coffre var på flere måder noert knyttet til det franske teatermilj $\phi$ i K $\phi$ benhavn: morbror til Marie-Madeleine Montaigu og Frederic Daniel Pilloy, som siden blev ledende skuespillere hos Holberg, således $i$ hans komedie Mascarade som hhv. Pernille og Leander i 1724. Le Coffre dфde 1722; hans hustru Marie-Hélène, fфdt La Croix, var da henvist til at forsфrge sig og sine børn ved at agere på komedien, bl.a. som den første Magdelone i Holbergs Mascarade.

Kongen, Frederik 4., havde fået smag for maskerade isar $i$ Venezia. I 1701 kunne man på Københavns Slot se »en pragtig Maskerade, hvor man saa Hoffet forkladt udi adskillige Nationers Habit, saasom tyrkisk, moskovitisk, persiansk og polsk «. ${ }^{3}$ Det svarer ganske godt til Le Coffres maleri. Og fra 1710 holdtes endog offentlige ugentlige maskerader på slottet, med almindelig adgang. Men synet på maskerne var ikke entydigt. Fra gammel tid var der isar fra kirkeligt hold en stark fjendtlighed mod masker og maskering, som ansås som suspekt, evt. djavelsk eller hedensk, og i hvert fald knyttet til kaos og tøjlesl $\phi$ shed. ${ }^{4}$ Men heller ikke den forfinede hof-form er uproblematisk. Modviljen, isar fra religiøs side, er tydelig. Da de offentlige maskerader 1710 indfores, udbeder kongens gudsfrygtige bror, prins Carl, sig et responsum fra kgl. Confessionarius dr. theol. Peter Jespersen. ${ }^{5}$ Dr. Jespersen svarer, at vel kan maskering i sig selv, »og at gifve sig ud for en anden end mand er «, fx på teatret, ikke som sådan fordømmes; altså et relativt liberalt teatersyn, sammenlignet med fx det gammel-ortodokse, som relaterede området til det sjette bud. ${ }^{6}$ Men blandes i maskeraderne pфblen med folk af stand, er iflg. Jespersen utugten og forargelsen ude, "hvor Enhver uden Distinction maae komme, gemeen Canaille, som ikke burde tillades at vare blant høie, fyrstelige Personer «. Så-

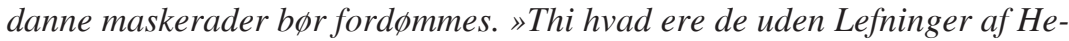
denskabet ... Derved forf $\phi$ res og mange unge Mennesker paa onde Veje, til at forspilde deres Velfard, ja evig Salighed «. Dr. Jespersens underforståede kritik af kongens maskerader er i og for sig uden forbehold. Og dog. Der er sprakker i betragtningerne: »Eet er at gaae derhen frivillig, af sig selv, ex pruritu, af Behag og Plaisir, et andet ex officii politici causa, og efter Befaling af den høie Øvrighed «. Med bevidst ulyst, efter ordre og i embeds medfфr stiller sagen sig altså anderledes. Hertil kommer, at høje herrers adfard må vurderes med megen tålsomhed: »Havde Lutherus brugt den mod Henricum VIII, havde Engelland paa denne Dag varet Luthersk«. Tendensen til fordфmmelse tager siden til og specificeres. De klassiske argumenter mod fiktion og masker, hentet fra kirkefadrenes nyplatonisme - og dermed fra Platon-mobiliseres $i$ de folgende tiår.

Maskeradeinstitutionen var i det bredere perspektiv en raffinering af en mere folkeligt upoleret maskebrug, der levede videre knyttet til årstidfester og 
under idelig bekcempelse fra verdsligt og gejstligt hold. Et reskript af 14.1. $1712^{7}$ udstedte forbud mod bl.a. at maskere og forklaede sig og handler formentlig om maskelфb i julen; det sker under henvisning til den netop overståede pest. Men da en bestemmelse 20.12. 1726 om uorden bl.a. ved juletid tager forbudet op igen, denne gang også med henvisning til Danske Lov, og refererer til »Masquerede og Formummede«s adfard, ${ }^{8}$ har der varet bredere årsager end som så.

Det siger derfor sig selv, at da der efter Den store nordiske Krig indrettedes et offentligt forlystelsescenter i København, et danse-, musik-, spille-, maskeog komediehus, ja, da aktualiseres diskussionen. Altså den totalitet af aktiviteter, som hører under begrebet fest, og som bl.a. kendes fra de italienske operahuse. Det er de funktioner, som afbildes på Le Coffres loftmaleri, men altså nu i versionen borgerligt kommerciel institutionalisering af maskeraden. Festcentret havde frem til 1721 til huse $i$ Giethuset, oprindeligt et kongeligt kanonstøberi, på Kongens Nytorv; men fra januar 1722 var placeringen i et nyt specialbygget hus i Lille Grønnegade, der senere på året kom til at danne ramme om det første professionelle nationalt-sprogede teater i Norden. Etablissementets privilegium angik såvel komedier som maskerader. ${ }^{9}$ Også skuespillerne selv arrangerede maskerader $i$ huset, således Johan Ulsфe, i $\phi v r i g t$ den første Jeronimus i Holbergs Mascarade. Étienne Capion, der stod for etablissementet, var presset $\emptyset$ konomisk, bl.a. efter en tur i gaeldsfangsel, og han satsede på maskeraderne som indtcegtskilde. Men 10.2. 1724 udstedtes et forbud mod offentlige maskerader. Årsagen angives at haenge sammen med hasardspil. Men noget uklart er det. Det er givetvis den generelle natlige uro, man vil til livs. Forbudet skal ses $i$ en sammenhang med de netop omtalte indgreb mod de formummedes løssluppenhed i fx jule- og spillestuer, som vi har set bl.a. med henvisning til Danske Lov. Det er da også bemarkelsesvardigt, at maskerader ved udtrykkeligt forbud er undtaget fra det tilladte, da privilegiet påny udstedes efter pietismen $i$ 1747, efter at teatret af religiфse årsager havde varet lukket i noesten tyve år; assembleer - og det er til dem spil er knyttetvar tilladte, men ikke maskerader »som aldeles skal vare forbudne". "Maskerne tillades ej hverken hos den ene eller anden og forbydes over alt« lyder en conseil-beslutning fra 1747; forbudet gentages $1750 .{ }^{10} \mathrm{~F} \phi r s t ~ 44$ år senere, ved reskript af 2.4. 1768, åbnedes igen for maskeraderne på komediehuset. Det kan altså ikke vare problemet med hasard, der var altafgфrende. Det var knyttet til assembleerne. Der er en rest af en anden motivering. Maskeradebegrebet var i sig selv periodevis kontroversielt.

Men også selve teatret gjorde vidtstrakt brug af masker på scenen. ${ }^{11}$ Forestillingerne havde $i$ kraft af deres forening af kunstarterne i langt højere grad karakter af Gesamtkunstwerk end man siden har opfattet. Teaterforestillingen 
indgik organisk i det samlede rum, illusionens hus, komedie- og maskeradehuset, som komponent $i$ dets begreb om fest; der var tilskuerpladser på scenen og ensartet belysning af scene og sal. Ganske som maskeraderne var selve komedierne genstand for angreb, man fór ud fra Universitetets side med en rakke sager under henvisning til, at skuespilleri var ensbetydende med et uanstandigt levned. Tilmed stemte professor Holberg $i$ konsistorium for, at der blev skredet ind mod de studerende, som optrådte i hans egne komedier! En realpolitisk manфvre, som afspejler hvor hårdt presset var.

Både teater og maskerade var $i$ en vis forstand nye fanomener, man skulle forholde sig til, flyttet fra hof-sammenhonge til urbaniseret-borgerlige, egentlige forlystelser på kommercielle og professionelle prcemisser. Lykkedes det ikke umiddelbart at få lukket komediehuset, blev der imidlertid som navnt nedlagt forbud mod maskeraderne. I perioden omkring forbudet i 1724 forfattede J.R. Paulli, Holbergs konkurrent, komedien Julestuen og Maskaraden, som aktфrerne dog fandt for ringe til at opfфre. Holberg foretog nu et sikkert og lykkeligt kirurgisk snit og kreerede to komedier, Juele-Stue og Mascarade. Sammenstillingen er interessant: med julestue-komedien tegner Holberg et billede af den animalske fest, den provinsielt-tilbagestående manifestation, et dybt umoralsk karikerende billede af praciviliseret eller-urbaniseret form $\phi r-$

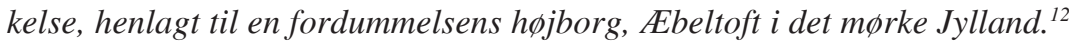
Sat op mod Juele-Stue er Mascarade en afbildning af den moderne, civiliserede eller sakulariserede version af den maskefest, som har at gфre med cyklisk magi, men hvis formål nu primart er civil-socialt. Sådan er den historiske udvikling $i$ et st $\phi r r e ~ k u l t u r p e r s p e k t i v$, den raffinerede institution bygger på den årstidsrituelle, som hernast anses som primitiv og tilbagestående. ${ }^{13}$ maskeraden som den civiliserede udgave af karneval, det kaos af masker og magi, som råder også $i$ Juele-Stue, hvis kritiske portrat affesten stemmer overens med periodens generelle oplysningsprojekt - som i andre sammenhange kunne vare religiфst motiveret. Denne forskydning er endvidere ganske analog med det nye komediehus' overordnede teater-koncept, som husdramatikeren Holberg formulerede det: en demonstrativ distancering fra den eksisterende spektakulare og »u-ordentlige« norm, og i stedet installeringen af et moderne civilt engageret teater. Overordnet er der tale om et gedigent udtryk for det afgфrende paradigmeskift mellem ancien og moderne, mellem 1600- og 1700tal, mellem metafysik og prosaisk ratio.

Holbergs omgang med fanomenet maskerade $i$ komedien af det navn er på alle måder interessant. Den er selvklart en apologi på vegne af det betrangte teater. $\mathrm{Og}$ det er da i den forbindelse bemarkelsesvardigt, at stykket således implicit kritiserer det regime, forfatteren selv forfagter. Når han forsvarer teatret, er det med henvisning til dets moralske nyttevardi. Slet så enkelt er det 
ikke med maskeraden, som pr. definition er galskab og ufornuft. Hans apologi er mere radikal. Komedien er mere end et lejlighedsstykke. Der ligger en dybere metaforik som klangbund for komikken.

Komedien blev opfort $i$ selve festhusets dansesal, tilmed $i$ karnevallet/fastelavnen på tarsklen til fasten. ${ }^{14}$ Som Le Coffres maleri »foregår « den det samme sted, som den afbilder. Det er teater om og på teatret. Tilskuerne får tildelt rollen som sig selv. Maskeraden på scenen bliver derved konkret mere »virkelig « end komediens anden lokalitet, borgerhjemmet, som jo er scenografi, illusion. Dette manifesterer i sig selv komediens grundparadoks.

I al korthed går komediens plot ud på, at den unge herre Leander er $i$ den grad optaget af at gå på maskerade ledsaget af tjeneren Henrich, at han gфr nat til dag og derfor forsфmmer at aflagge bes $\phi g$ hos sin trolovede Leonora, som han i фvrigt ikke kender. Husfaderen Jeronimus raser, mens mor Magdelone lurer på selv at gå på maskeraden. Henrich sфrger for at de slipper afsted, og på maskeraden forelsker Leander sig i en ukendt jomfru, hvorfor han er parat til at bryde forlovelsen. Leonoras far Leonard, som for besindigt har forsvaret maskeraderne, mister nu moderationen, forstarket af at også hans datter er til sinds at bryde forlovelsen, da også hun har forelsket sig på maskeraden. Nu er fanden l $\phi$ s, bl.a. fordi der var en fordelagtig $\phi k$ onomisk transaktion forbundet med alliancen, alt synes at styre mod katastrofen, indtil det afslores, at den ukendte, de unge hver isar har mфdt, er den, de var forlovet med og altså nu med dobbelt fryd kan agte.

Forl bbet er på det overordnede plan spandt ind i en pedantisk velordnet struktur over tre akter, med velmotiverede entreer og omhyggelig tidsangivelse $e^{15}$ - vi bevager os fra en prasentation til en komplikation, via en opskruning mod en desperation ud i en forlфsning - den patriarkalsk perfekte dramaturgi styrer afviklingen af historien, ikke det glade anarki, modsat julestuekomedien. Men i forhold til helstrukturen er delstrukturerne underligt fragmentariske. Planer, viljer, intriger kommer i adskilte forl $\phi b$. F $\phi r s t$ handler det om, at Leander og Henrich vil på maskerade. Der opstilles en forhindring; den overvindes. Derefter skifter fokus til forelskelsen. Disput-scenen satter forl $\phi$ bet $i$ stå, som en blok for sig i lighed med tamperrets-scenen, Henrichs komedie-i-komedien. I slutningen af anden akt sattes en frist: Leander skal vare gift $i$ aften. F $\phi r s t$ i komediens trediesidste scene sattes en rudimentar intrige i gang; hensigten er at korrigere det fadrene stivsind ved at overtrumfe dets konsekvenser. Det sker gennem den falske nyhed om, at Leonora har begået selvmord. Men da er komedien naesten slut. Det er vanskeligt at tale om dét drivende projekt, ligesom man kan spфrge sig, hvad det egentlig er for en tematisk konflikt, der lфses op i slutningen. At de unge mennesker tilfaldigvis er lфbet ind $i$ deres tilkommende, beviser vel ikke generelt maskeraders nytte, 
som havdet af Henrich? Der anes allerede i kompositionen en modstilling mellem regularitet og anarki: som i Le Coffres maleri en dramaturgi, der kombinerer en overordnet komposition med disparate detaljer. Går man tat på, oplфses billedets tilsyneladende overskuelighed, orienteringen glipper.

Titlens Mascarade indebarer en eksistentiel metafor. En dobbelthed $i$ komedien som i maleriet: dokumentariske udtryk, der samler sig til et flimrende billede af uhåndgribelige tilstande. Kampen om maskerade-metaforen er i høj grad haftet op på kampen mellem generationerne. Desto mere interessant er derfor autoritetskonflikten i komedien. Den lases normalt som et forsvar for ungdom og letsind og imod den aldre generations forstokkethed, den er blevet forstået som en »forsynskomedie ": ${ }^{16}$ storre og dybere krafter griber ind $i$ de menneskelige dispositioner og tilføjer lykken nye dimensioner. De gamle bliver til nar ved skabnens indgriben. Eller er det de unge? De gamles vilje går jo i opfyldelse.

Såvel sфnnen som hustruen trodser husfaderen, Leander vil endog gifte sig mod sin faders vilje. Familien er et mikrokosmos billede på det absolutistiske makrokosmos, Holberg levede og agerede i. Magtens og autoritetens tema optog Holberg fra forste fard, han var for sin tid sardeles moderne i sit syn herpå. Magten var herefter ikke metafysisk, men rationelt motiveret-svarende til det sekulare syn på fest og teater. I sit retsfilosofiske gennembrudsvark, Introduction til Naturens og Folke-Rettens Kundskab, udgivet 1716, beskrev han suveranens beføjelser og lod dem reflektere familiens magtbalance. Grundlaggende refleksioner over naturens lov udgår fra, at »saasom Menneskets Ondskab langt overgaar Basternes, saa er det nфdvendigt, at dets Frihed paalegges en sterkere Tфmme", og der »findes hos Menneskene stфrre Ustadighed og Forandring end hos noget andet Slag af Basterne $"{ }^{17}$ Derfor har den enevaldige fyrste en autoritet, som reflekteres $i$ husfaderens myndig-

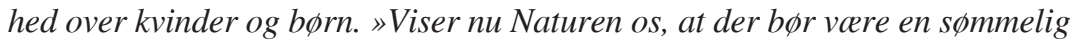
Orden udi en Husholdning, saa befaler den ogsaa at skye Ting, som forvirre og фdelegge Familier, hvoraf enhver er som en liden Regiering. "Ganske vist hedder det, at mandens herredфmme er afledt af den hellige skrift, ikke af naturens lov. Og ofte er kvinder bedre skikkede til at regere end mand. Men ved en art contrat social har kvinden undergivet sig mandens herredфmme, »som maa vare mild og holdes ved lige heller ved Kiarlighed end Frygt, givende Manden ikke Jus vitae og necis, ey heller Magt at bruge nogen haard Tvang «. Magdelone i komedien bryder denne basale orden; til gengald kan det diskuteres, hvorvidt Jeronimus praktiserer sin autoritet med karlighed. Om børns pligter over for deres forcldre, som jo mildt sagt er et hovedmotiv i komedien, spфrges det bl.a., om aegteskab indgået uden forceldres samtykke er gyldigt; og der svares, at vel er børnene pligtige at rådføre sig med forceldrene i agte- 
skabssager, men gør de det ikke, er forbindelsen ikke af den grund ugyldig. Først når sønnen har forladt familien, er han ikke underlagt faderens regimente, »men er alleene forbunden til en sønlig AErbødigheds Pligt«. Men så føjes der til - og det er en tilføjelse fra 1728-udgaven, Holberg har altså ikke modificeret, men tvaertimod strammet opfattelsen: "Dog giфr et Barn en lastelig Gierning, naar det gifter sig med een, som Forceldrene ikke anstaar, saasom det er en Fader høyt Magt paaliggende, at ingen Sviger-Søn eller Sviger-Dotter imod hans Villie bindes ham paa Armerne ${ }^{18}{ }^{18}$ Det er pracis, hvad Leander og Leonora står i begreb med at gфre. Og hvad de ifølge komediens forfatter faktisk ikke burde gøre. De kommer i konflikt med det forhold, at »Forceldrenes Herredømme over Børnene haver sin Oprindelse af Naturens Lov ... Til at $\phi v e$ saadan Omsorg udfordres Magt til at regiere Børnenes Gierninger til deres egen Velfcerd..." Den magtfordeling udspringer af, at »Børnene holdes for at have givet deres Samtykke dertil: thi man kan slutte, at dersom et Barn ved Fødselens Tid havde Skiфnsomhed, og saae, at det uden Forceldrenes Omsorg og Herredømme over sig, ikke kunde bestaae, det da frivilligen skulde samtykke til saadant Herredømme, og derimod betinge sig, at Foraeldrene vilde have Omsorg for at opdrage dem«. Her er vi ved kernen: det er med rene ord contrat social-tanken, der involveres, ideen om delegeringen af magten, som folket formodedes at overdrage til suveranen, der derncest var garant for orden og sammenhang. Om den faedrene magt siges det, at »Naturens Ret befaler ham at opdrage Børnene saaledes, at de kunne blive nyttige Lemmer udi det menneskelige Selskab ... dersom Børnene foragte all Tugt, og der er intet Haab om Forbedring, kand Forceldrene slaae Haanden af dem, eller drive dem af deres Huuse ... saa lange de ere udi deres Foraldres Huuse, ere (de) forbundne til at følge deres Myndighed ... For Resten maa alle Børn uden Forskicel vare ydmyge, og arbødige mod deres Forcldre«.

Her siges ting, som er så centrale for laesningen af komedien, at den umiddelbare tagen parti for ungdommen bringes i tvivl. Et andet billede toner frem: billedet af Leander som en Holbergsk hovedfigur besat af en last eller brist, der skaber uorden i de sociale relationer, og hvorfra han ved komedieintrigens hjalp skal hentes tilbage til virkeligheden, »helbredes «. ${ }^{19}$ Jo, men, kunne man så indvende, der er jo åbnet en kattelem ved kravet til faderen om karlighed, ifald han ikke opfylder det, er han vel ikke nogen legitim regent... Men, $i$ analogi med princippet om at undersåtten er pligtig også at give sig ind under den slette fyrste, at tyran-mordets mulighed altså ikke er en given sag, så siges det $i$ kapitlets konklusion, at børnenes pligt er, »at tiene, are og adlyde deres Forceldre, intet vigtigt at foretage uden deres Raad, og liide taalmodig de Skrøbeligheder, som findes hos dem. "Herefter burde Leander faktisk føje sin fa- 
der, der da også III, 4, henviser til »den Magt og Myndighed, som GUd og Naturen har givet Forceldre". Tungere argumenter findes ikke.

Senere tiders uvilje mod at involvere denne type ubekvem kontekst i tekstlasningen fortranger den splittethed $i$ Holbergs kunstneriske univers, som omfatter såvel mennesket som zoon politikon, et dyr med evnen til at danne samfund, som billedet af homo homini lupus, mennesket som menneskets ulv, hildet i blinde drifter, som må disciplineres, ifald den ultimative massakre skal undgåes. ${ }^{20}$

Skifter vi nu optik og går ud fra modpartens syn, Henrichs apologi for maskeraden, II,3, ses det, at centrale passager i dialogen har karakter af egentlige disputer. Kombattanterne er Jeronimus og Henrich. Sekundant er Leonard. Denne dialogform er ikke utypisk for tiden - $i$ andre sammenhange end teatrets. Henrichs apologi indledes med, at han forsvarer sig mod anklagen for at følge sin herre ind i dansesalen: det hindrer det forfald på sjal og krop, som de barske kår som tjener byder ham, han får motion. Det ville du også få ved at hugge brande, replicerer Jeronimus. Henrichs modargument handler om at lysten driver varket. Og i фvrigt er dansen ungdommens tidsfordriv, drukkenskab alderdommens - hvad der medfører en loftet stok fra Jeronimus. Problemet er dybest set, at maskerader er noget nyt, siger Henrich med en for sin forfatter typisk relativisme: moder er underlagt tilfoldighedens lov, ikke naturens. Jeronimus strammer nu grebet: maskerader giver anledning til usaedelighed. Ikke her i landet, lyder svaret, dertil er omgangelsen i forvejen for utvungen. Moderationens talerør, $h r$. Leonard, blander sig: bliver man ikke en døgenigt af at buldre hele natten? Jo, men vi går der kun 5-6 gange årligt svarer Henrich. Her bryder den tilsyneladende seriфse argumentation sammen; det er ganske enkelt løgn, hvad han siger. Henrich snyder konsekvent på vagtenganske som han I,10 uden skrupler franarrede sin herre en daler under påskud af at ville hjolpe ham. Hans argumenter er skinargumenter. Han fortsatter med at forsvare nattesvir med, at den harder ungdommen og ruster den til fremtidige strabadser! Det er sofisteri og parodi på en argumentation, en Erasmus Montanus vardig, smukt fulgt op, da Jeronimus fremhaver det skammelige $i$ at gøre nat til dag og omvendt - og får svaret, at det gør jo alle vagtere! osv. osv. Herefter tager Leonard over og udtaler de ord, som siden dukker op i Epistel 347, at maskeraden er et billede på den naturlige tilstand, førend menneskene hovmodigede sig over for hinanden, og at leg og tidsfordriv kan vare nødvendig som mad og drikke. Det er blot excessen, der må fordømmes. Hvorefter Henrich farer fort i sit verbale amokl bb: hans danselyst skaber arbejdspladser - hertil bemarker Jeronimus, at man vel næeppe spiller kort for at beskaftige kortmagerne... 
Henrich er den eneste, der bevarer kontenancen stykket igennem, da han ikke er bundet af smålige hensyn til sandhed og logik, kun til den absolutte relativitet. Stykket starter da også med at han vil satte tiden ud af kraft og flytte på solen, fikspunktet, fadertegnet - hvad der går lige over $i$ en forveksling affaderen, »Papa«, med papegøjen i buret, frivolt spraglet som Harlekin eller selve den »changeant Domino med Masque«, Henrich siden barer på maskeraden. ${ }^{21}$ I første og anden akts åbningsscener trakker han maskeradens kaos med ind, natten og drømmen. Leonard som moderationens fortaler dementerer sig radikalt, da han under indtryk af kaos dels taber civilisationens maske, dels afslфrer de egentlige, фkonomiske, motiver til agteskabsprojektet, III, 11. Da Leonard mister den sikre orientering, virkelighedsrelationen, retter han følgende svada mod datteren: "Jeg veed ikke bedre end at du gaaer paa Mascarade $i$ Aften igien, at du kand forliebe dig udi den anden, i Morgen Aften udi den tredie, og fare saa stedse fort, indtil du kand faa saa mange Kicerester, som der bliver Mascarader i Aaret til. Saa kand du med Tiden paa en Comoedie blive en perfect Actrice, hvis Maade er at gifte sig engang hver Aften $\aleph^{22}$ - han bruger med andre ord teatret som metafor på det upålidelige, troløse, uberegnelige, jf. tidens opfattelse af teatrets dubiфse karakter, og jf. billedet af Henrich som en (skue)spiller, der tilmed demonstrerer sit sande vasen ved at spille en lille komedie-i-komedien $i$ tre små akter, centralt placeret: nøjagtig $i$ midten af den »store "komedies tre akter. Desuden agerer Henrich spфgelse og rabbi, altså dødning og hedning - som akkompagnement til maskeradel karnevalstemaet, som i sidste instans handler om en »anden «, ukristelig, dimension. ${ }^{23}$ Henrich evner ubesvaret at skifte identitet, de andre ikke at gennemskue det. Qui nescit simulare nescit regnare er et dictum, som dukker op igen og igen hos Holberg: kun den, der kan fingere, altså spille komedie, formår at styre (fx sig selv?). Henrich ender forestillingen med at konstatere, at »Her er spillet en Comoedie«. Hvis? kunne man spфrge...

Henrich er en central Holbergsk figur, illusionsløs. Det intelligent improviserende og usentimentalt manфvrerende menneske er en type, som fremhaves med prototypen Leander i Hexerie eller Blind Allarm, Holbergs apologi for teatret, hvor han er skuespilleren, som tages for heksemester og magter at udnytte situationen selv uden at have indblik i misforstålsen.

Holberg lagger her og der Jeronimus betragtninger i munden, som han selv har fremfort bl.a. $i$ sine Epistler. ${ }^{24}$ Det samme galder andre af personerne, som altså hver på deres vis er forfatterens talerør med synspunkter, som indbyrdes dementerer og ophaver hinanden. Altså en indikation af, at en rakke laesninger kan gennemføres, som alle samtidig er til stede, og som bidrager til komediens uhyre kompleksitet, dens fraver af arkimedisk punkt, hvorfra analysen med sikker hånd kan gennemføres. Afhangig af hvor man laegger snittet, 
har de hver på deres vis ret alle. Henrich er den totalt fluktuerende, han er komediens midtpunkt ved at vare uden centrum, uhåndgribelig som teatret eller maskeraden. »Han er Hjulet, som driver alting «, - ikke »det hele«, men »alting « siger Jeronimus, III, $7 .{ }^{25}$

Under Holbergs sokratisk-aristoteliske idealer om moderation og middelvej ligger en yderst bitter erkendelse af vilkårlighed som vilkåret. Nappe nogetsteds har han formuleret det starkere end $i$ andet skamtedigt fra 1722, »Apologie for Sangeren Tigellio«, formet som en dialog, hvor titelpersonen, sangeren Tigellius' absolutte ubestandighed, er til diskussion, med den overraskende argumentation, at eftersom mennesker, byer og hele nationer er gennemsyret af tilfceldighed og uberegnelighed, er Tigellius billedet på verden, på mennesket, når det er »uden Masque«, »thi i hvert Menneske en selsom Chaos er«. Jeg vil uden tøven karakterisere maskeraden hos Holberg som en sådan »selsom Chaos". Digtet lфber ud i et morads af paradokser, en generel kapitulation i forhold til at skulle gribe og begribe mennesket: »Jeg Definition ey bedre kand formere/ End det er Dyr som man kan ikke definere". I det foregående skamtedigt om »Democritus og Heraclitus « sattes to filosoffer op over for hinanden, den forste fyldt af sorg og radsel over menneskenes vildskab og dyriskhed, den anden af latter over deres tåbelighed. På komplementar vis siges det, at mennesket på én gang er det cedleste og det hoesligste, måske i al hast skabt af guderne i sanseløs drukkenskab; da de vågnede af rusen, brød de ud i latter over deres skabervark. Derfor er kun dén en sand filosof, »Der $i$ hvert Øyeblik tungsindet er og kaad«, altså praktiserer en komplementcer sarkasme. Konklusionen mht. de to filosoffer er, at »den eene grad med Grund, den anden bedre loe ". En tilsvarende, noermest Swiftsk misantropi råder $i$ Metamorphosis ${ }^{26}$ fra 1726, Holbergs anti-Ovid digt, hvor dyr og planter straffes ved at blive transformeret til - mennesker! Bag den menneskelige maske lurer en dyrisk sandhed. Maskeraden er et indblik, mere reel end realiteten. Derfor er den til nar, som fornagter maskeradens sandhed, havder virkelighedens virkelighed.

Overlevelsesstrategien i denne universelle relativitet, dette basale bestiarium, er dobbelt: i positionen mellem fortvivlelse og latter et valg af maske, distancering, refleksion. Og en insisteren på at refleksionen åbner for en indsigt i relativiteten og dermed for et rationelt handlingspotentiale. ${ }^{27}$

Vidnesbyrd om Holbergs relation til billeder i gangs forstand er naesten ikke-eksisterende. Der er dog et par undtagelser. Til sit segl valgte Holberg billedet af klippen, som står fast i brcendingen og brandstormen, og med påskriften »Bestandighed «. Det ligner en besvargelse af kaos. Det er klart, at det også spiller på kontrasten mellem det substantielle og det futile, behovet for at installere en disciplinerende instans. Og som sådan knyttet til Jeronimus. 


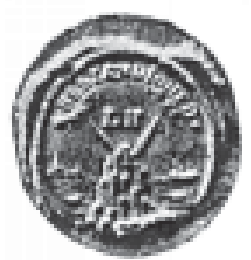

Holbergs segl. Til højre en forstørret tegning heraf.

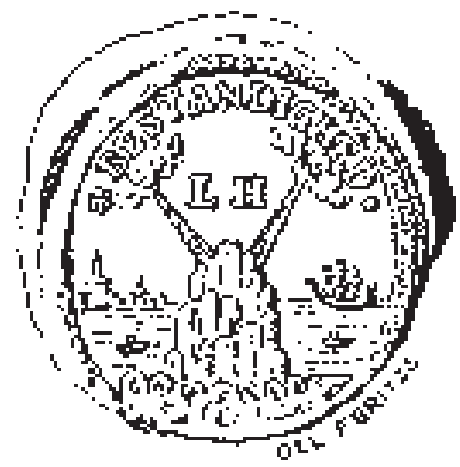

Holbergs spadserestok findes bevaret. Dens håndgreb udgøres af en svane, som napper $i$ en narrenase på sit eget bryst. Man har aldrig varet $i$ stand til at udlagge en mulig symbolik. Et 1600tals-maleri på Skokloster ved Stockholm viser imidlertid en tilsvarende emblematisk situation med påskriften »Nosce te ipsum «, kend dig selv (se naste side). Det var altså det allegoriske billede, Holberg støttede sig til på sin vandring. Men at kende sig selv, betød jo at kende kaos. Det er Henrichs erkendelse.

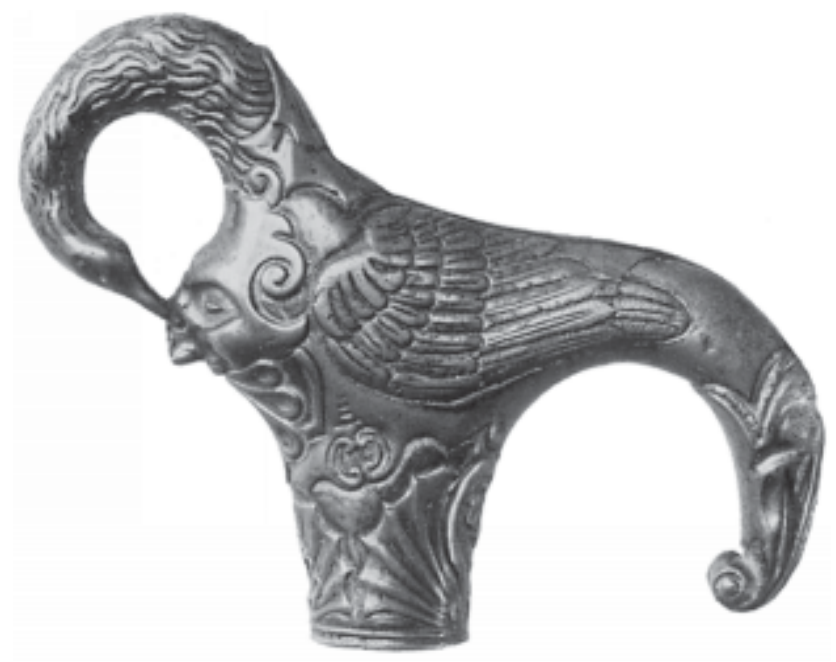

Henrich er professionel. Kun den illusionslose kan operere i illusionen. De $\phi$ vrige er hildet i deres forestilling om at besidde en indsigt og agerer derfor $i$ en komedie, de ikke opfatter.

Holbergs stokkehaindtag. Dansk Folkemuseum.

\section{Fiktionens tvetydighed}

I 1728 brandte Kфbenhavn, teaterdriften indstilledes, med helligdagsforordningen af 1730 indskarpedes snavre granser for den slags fest-aktiviteter- 


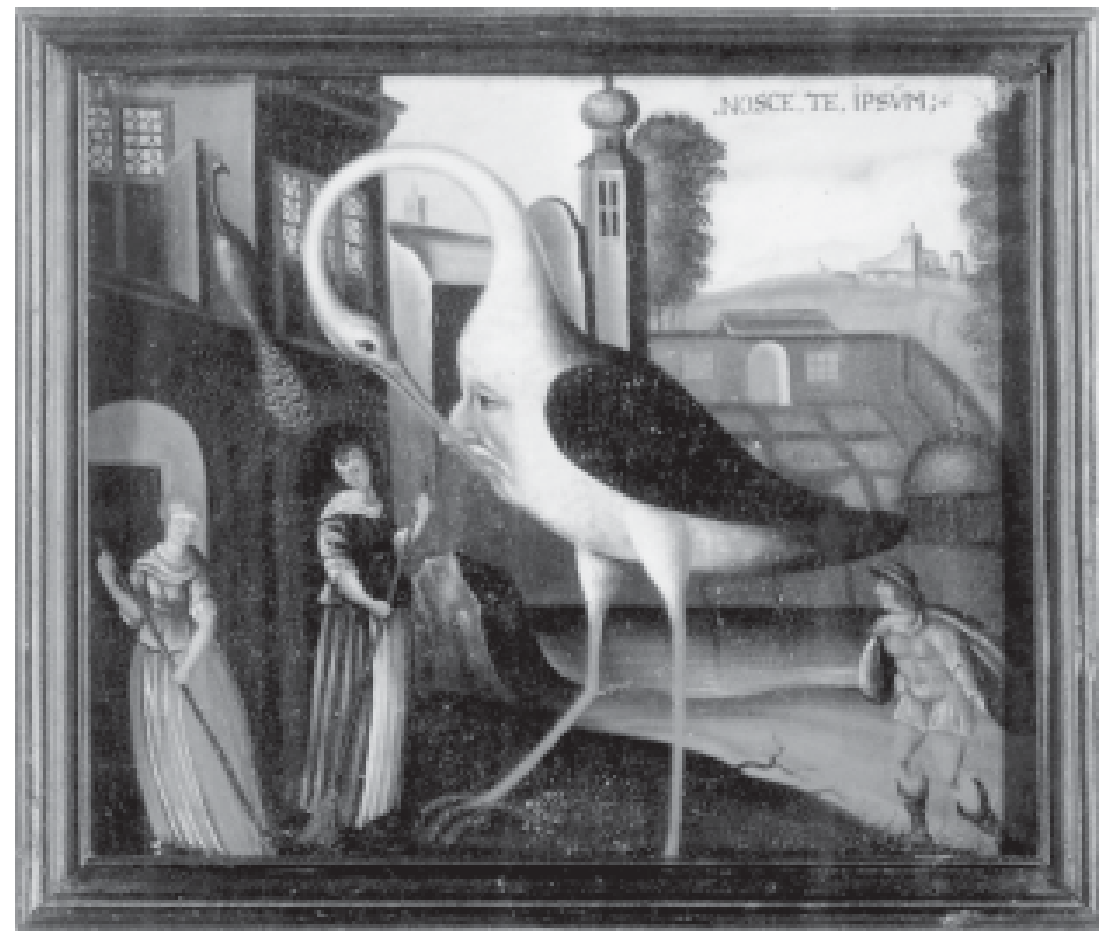

Nosce te ipsum. Maleri 1600-tallet. Skokloster.

komedie, maskerade m.v. - som havde varet knyttet til skuespilhuset. Det er den nasten tyve år varende teaterlфse tid. Aret for byens brand udkom en oversattelse af den tyske kristelige moralist Chr. H. Amthors De jure decori. ${ }^{28}$ Heri ivres mod maskeraden: „... at det hele Selskab lфber mange Timer imellem hverandre masquerede omkring ... er en hфyst-strafvardig Ting, og giver gandske u-feilbarligen Anledning til allehaande Skam og Lyst, fordi ingen veed til fulde, hvem der har gjort det... «Det undrer derfor forfatteren, at gejstlige ikke pradiker mere massivt mod denne misbrug. Det kom.

I sin Everriculum - dvs. »Fejekost til at udfeje den gamle Surdejg eller de $i$ de danske Lande tiloverblevne og her for Dagen bragte Levninger af saavel Hedenskab som Papisme - fra 1736, reformationsjubilaumsåret, året for indforelsen af den almindelige konfirmation, dissekerer den toneangivende teolog Erik Pontoppidan bl.a. fastelavns mandag, hvor djavelen med alskens lokkemad søger at få sjalene på krogen, festen er som romernes bacchanalier, og kvinderne tér sig som de rene bacchantinder; vi cimbrer er af italerne blevet smittet »med denne Rustplet paa Saderne «. ${ }^{29}$ Pontoppidan fortsatter nu: 
»Hidhen hører ydermere Maskespillet, som gemenlig paa de Franskes alamodiske Sprog, der nu om Dage har den polerede Verden til Beundrere af sin Finhed, kaldes Masquerade; hvorved paa selve Tarskelen til den hellige Faste meget ofte Hoffernes Letfardighed som det sletteste Forbillede kappes i Paatagelse af fremmed Skikkelse og forborgne Aasyn med Comoedie-Gøglets lystige Paafund. Men, I Chamaleoner! lader Eders Øren staa vidtaabne for Theologernes Phoenix, den salige Doctor Hector Gothfred Masius, som med et sandt hectorisk Slag rammer Maskernes Bedragelighed og afleder den Art Polyp-Forvandlinger, som vi kalde Forkladelser og Mommerier, fra Djavelen selv, som var den første, der paatog sig en ny Skikkelse for Beboerne af Paradisets Dal, og fra Hedningernes Blindhed, hvilken man paa en Maade maa bare over med, saasom de ikke kendte det guddommelige Forbud, som mфder os i 5. Mosebog, 22. Capitel, Vers 5: Der skal intet Mandstøj vare paa en Kvinde, og en Mand skal ikke fore sig i Kvindeklader; thi hver den, som gør disse Ting, er en Vederstyggelighed for Herren din Gud.«

Der skelnes altså ikke mellem den primitive almuebrug og de velstilledes og oplystes mere raffinerede eller civiliserede udfoldelser: hofmand, købmand m.fl., »hvilke næeppe kunne holde sig i deres gode Skind, medmindre de hver Dag finde Adspredelse blandt Masker, Comoedianter, Danseballer ... og andre Narrestreger af samme Surdejg, Forlystelser som ingenlunde ere sundere end Almuens Jule- og Fastelavnsmorskab! Thi de flyde af samme saare plumrede Kilde, nemlig et forfangeligt og af lutter Vellyster sammensat Hjarte, hvilket markeligt afviger fra Salomons Visdom, som siger: Latter, du est galen, og: Glade, hvorfor gør du det?" Rester af hedenskab er det, og teater slås $i$ hartkorn med maskeraden $i$ en afskyelig kappestrid på falskhed og bedrag, »Paatagelse af fremmed Skikkelse og forborgne Aasyn", udgåede som de begge er fra lognens fader, som var den forste, der ved maskens hjcelp forledte til ur-synden i paradisets have. Pontoppidan havde den allerhøjeste bevågenhed, fra 1735 var han hofprest.

I 1740 udkom Eg. G. Hellmunds Teologiske Svar paa de to Spørsmaale: I. Om Dantz, som nu omstunder фves saa meget $i$ Verden, er Synd? II. Om Spill er Synd? oversat fra den tyske udgave af 1720. Her findes bl.a. anbefaling af at hugge brande (eller rydde op), hvis man har trang til fysisk udfoldelse, svarende til disputten mellem Henrich og Jeronimus, II,3: »Jeronimus: Kand dit Beest ikke movere dig, uden det skal skee ved Dantz? Kandst du icke giøre nyttigt Arbeyde og deraf bekomme sund Motion? Henrich: Jeg kand movere mig med at dantze, jeg kand ogsaa movere mig ved at hugge Brande... «. 
Dans har i følge Hellmund sin oprindelse i hedenskab og djavel, den indebarer »hoffardige, vellystige, ugudelige og farlige Geberder «, »Legemet bliver en Daarekiste og Syndehus«, som ikke kan huse helligånden. Dårekisten er et ofte genkommende tema. »Chorea est circulus, cujus centrum est Diabolus « dvs. at »Dantz er en Kreds, hvis Middel-Punct Dievelen er, 30 hedder det med henvisning til den hellige Augustin. I Mascarade foretager Jeronimus sammenstillingen dans/maskerade-horehus, I,7. Og Leonard konstaterer at overdrivelsen forer til dårekisten, II,3. Centraltermen i hele den kirkelige argumentation, vellyst, anvender han II,2. Det fadrene sproglige leje har diskret taget farve af tidens gudelige stil; som også når Jeronimus I,6 påbyder hustruen »Poenitentze«.

Ligeledes 1740 kom en udgave af Erik Pontoppidans Neue Erörtung der alten Frage: Ob Tantzen Sünde sey. Aus der Dänischen Sprache übersetzt. Det er en dialog mellem Eusebius og Philocosmus, dvs. »verdenselskeren «, $i$ princippet komponeret som den verbale pro-et-contra duel mellem Henrich og Jeronimus. "Dansesalen er forfangelighedens storste skueplads ", ${ }^{31}$ hedder det, her findes alle laster samlet, utilb $\phi$ rlig elskov vakkes. I »Assembleer eller danseforsamlinger « - sådanne, som havde varet på teatret $i$ Lille Grønnegade - driver Satan sit rasende spil. På dydens smalle vej levnes ingen plads til »drejninger og luftspring «. Ufatteligt er det, at visse ikke undser sig for at bedrive dans som profession i offentlighed, da synd jo normalt foregår $i$ det skjulte. »Der Teufel is der erste Tanzmeister gewesen«. Dårskab er i sig selv syndig. »Du skal ikke gфre dig til Harlekin eller til en lystig person i selskab, ikke svarte ansigtet, tage narrekappe på, spille fastelavn «, erklares det med skriften. Kirkefadrene mobiliseres mod dans, komedie o.l. hedenske relikter. Her er ingen pragmatiske sprckker som i dr. Jespersens responsum, som blev citeret $i$ indledningen.

Den kirkeligt-fundamentalistiske holdning går igen i et antal afhandlinger fra den sene pietismetid, som foreligger i håndskrift, stort set upublicerede, og som omhandler dans, teater og maskerade, der jo opvakker de onde lyster: er forbundet med vellyst. Heri opmales bl. a. skrcemmebilledet: hvad nu om jeg dфde i teatret, til komedie eller maskerade, hvad allerede dr. Jespersen og Pontoppidan var inde på, den første relativt liberalt, den anden nådesl $\phi s t$. Heller ikke her er der nogen slinger: det er den lige vej til helvede. Skrakeksemplet er den forfardelige operabrand i 1689, ${ }^{32}$ da en stor del af Kobenhavns bedste borgerskab omkom under reprisen af en kongelig hyldestforestilling. Det er klart, at det er truslen fra en genoprettelse af skuepladsen efter den pietistiske Christian 6.s d $\phi$ d, der huserer; og man maner altså til eftertonksomhed ved at fremhave en tidligere lejlighed, da majestaten lagde hus og navn til sådanne udfoldelser. Det er at gå forblфffende tat på suvercenen. En vis reaktion kom 
der ved tronskiftet. Erik Pontoppidan modtog en forfremmelse, han ikke kunne afslå: han blev udnavnt til biskop i Bergen. „Dér er der ingen teatre«, skal kongen have udtalt.

Ikke desto mindre hed det i teatrets fornyede privilegier af 29. december 1747 som navnt udtrykkeligt, at »Masquerader... aldeles skal vare forbudne«. Hvis det kun var hasard, der var problemet, kunne dét vel blot have varet forbudt. Det er ikke desto mindre den gangse forklaring på maskerade-forbudet. Forst $i 1768$ blev der som sagt atter givet tilladelse. Men da kun på komediehuset. Ikke for i 1803 gives maskeraden totalt fri.

Det moderne begreb om maskeraden, aldeles lфsrevet fra magisk-rituelle implikationer, den som afbildes på Le Coffres billede, har Holberg udviklet $i$ filosofisk retning i den centrale Epistel 347, trykt 1749 og udgivet 1750. Epistlen er givetvis en replik til den Pontoppidanske opfattelse. Da vi jo er $i$ forbudstiden, er det atter lidt bemarkelsesvardigt, at professor Holberg behandler det, som forbindes med uro og unytte. Epistlen er et forsvar for maskeraderne; Holberg satter sig altså for så vidt i Henrichs sted. Ordet maskerade synes mere at stфde end tingen selv, siger Holberg. Tåbelig og uanstandig går den for at vare, da den dog er nyttig og sindrig, al den stund den fremstiller menneskets naturlige tilstand, ligheden for opdelingerne blev indf $\phi r t, o g$ som sådan er »en Imitation af de gamle Saturnalier", jf. den kritisk-anklagende påvisning af den hedenske oprindelse hos bl.a. dr. Jespersen og Pontoppidan, men her altså fremfort positivt. Maskeraden er en "philosophisk Leeg«, da »alle derved erindres om den Tilstand, Mennesket ved forste Skabning af GUD er sat udi, og fra hvilken det formedelst Synden er faldet." Lighedstemaet, som hos Jespersen var en vederstyggelighed, fremstår her positivt.

Det er hr. Leonards definition, der her gentages, men med den vigtige tilf $\phi$ jelse, at naturtilstanden refererer til situationen før syndefaldet - også Pontoppidan relaterede masken til paradiset, men da direkte til damonien og syndefaldet, ligesom han henviste til menneskets »naturlige« afsmag for excesser som dans. I Holbergs begrebsverden er det, som følger efter naturtilstanden, dikteret af moder og konventioner og er altså i en vis forstand illusorisk, roller. ${ }^{33}$

Derfor er, hedder det videre i epistlen, det normale liv »en bestandig Mascarade«, som "paalagger os Masker, hvilke vi ved saadan Leeg ligesom nedlegge, og at vi egentligen ikke ere ret maskerede, uden naar vi gaae med blotte Ansigter. « Nøne masker kaldte Pirandello sine skuespil...

Appliceret på komedien er Henrich og maskerade-metaforen eksponenter for naturtilstanden, som altså demaskerer alt andet som rollespil. Holberg affardiger uden videre det teologiske argument om, at det er uanstandigt at for- 
klade sig, herunder at »Mand if $\phi r e$ sig Qvinde-og Qvinder igien MandsDragt«, som er blandt klassikerne i kirkens antiteater kampagner, og som vi jo også mфdte hos fx. Pontoppidan; »adskillige haarde Domme, som af Pradikantere faldes over indifferente Ting, kunde udkradses af vore Postiller «, f $\phi$ jer han til.

Men dette indebarer atter en komplet dobbelthed. Just naturtilstanden er det potentielle kaos, som faderautoriteten skal disciplinere, og omvendt er just naturtilstanden tilstanden før syndefaldet og altså lig det tabte paradis - og dermed en utopi $?^{34}$ Maskeraden er naturtilstanden.

\section{Kunstens sakramente}

Den Holberg-forståelse, der prager de følgende århundreder farves $i$ hфj grad af realismen/naturalismen. Og den er i høj grad under indflydelse af billedkunsten. I 1833 lancerer Adam Oehlenschlaeger den sammenligning, som herefter bliver klassisk: Holbergs kunstneriske udtryk er beslagtet med de store nederlandske mestre, den kraftfulde, jordnare (hverdags)realisme. ${ }^{35}$ Den poetiske realisme i romantismetiden, vaudevillernes nationale kleinkunst, koblet med

Vilh. Marstrand: Frands og Jeronimus

(bagest Jean de France). Tegning.

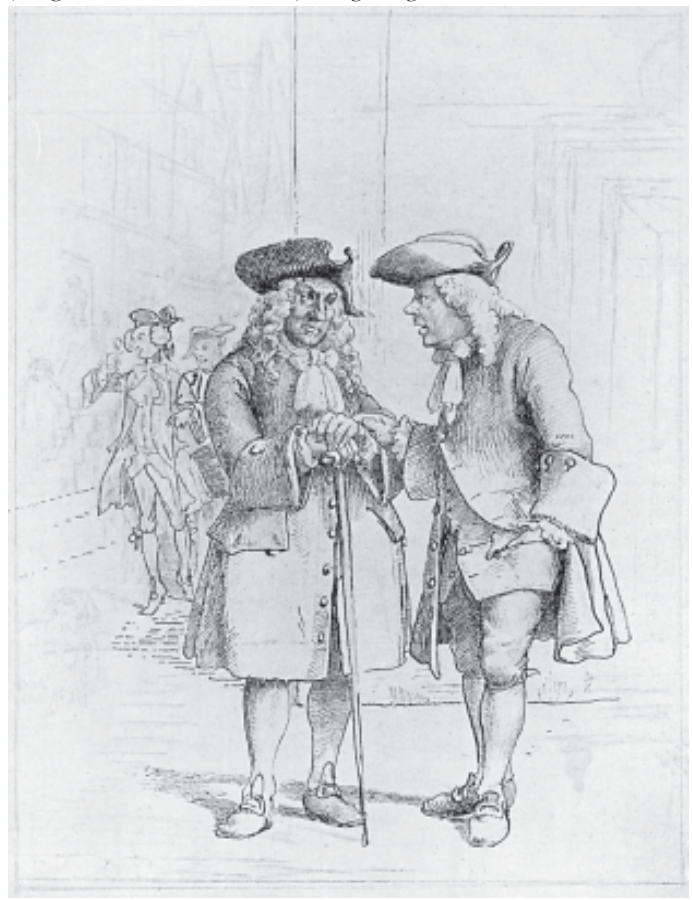

grundtvigske undertoner i billedkunstens fascination af folkelivet, ligger bag maleren Vilhelm Marstrands ganske store produktion af Holbergtegninger og malerier, som fik en normest granseløs indflydelse på den sceniske lasning af Holberg - og måske også på den tekstanalytiske? Marstrands tegninger og malerier er genrebilleder, en lun lilleverden bogstavelig talt befolket med små mennesker; Marstrand har en forkarlighed for at arbejde med lavstammede staturer - 
som en omvendt El Greco, kunne man sige.

Forfatteren til librettoen til Carl Nielsens opera Maskerade, premiere 1906, professor Vilhelm Andersen, stod som litteraturforsker for kontinuiteten $i$ dansk litteratur(forskning), i modsatning til Brandesskolens radikale markering af det moderne gennembrud; hans udgangspunkt er grundtvigsk praget; han beskaftigede sig med en sarlig forkarlighed med dansk guldalder, altså

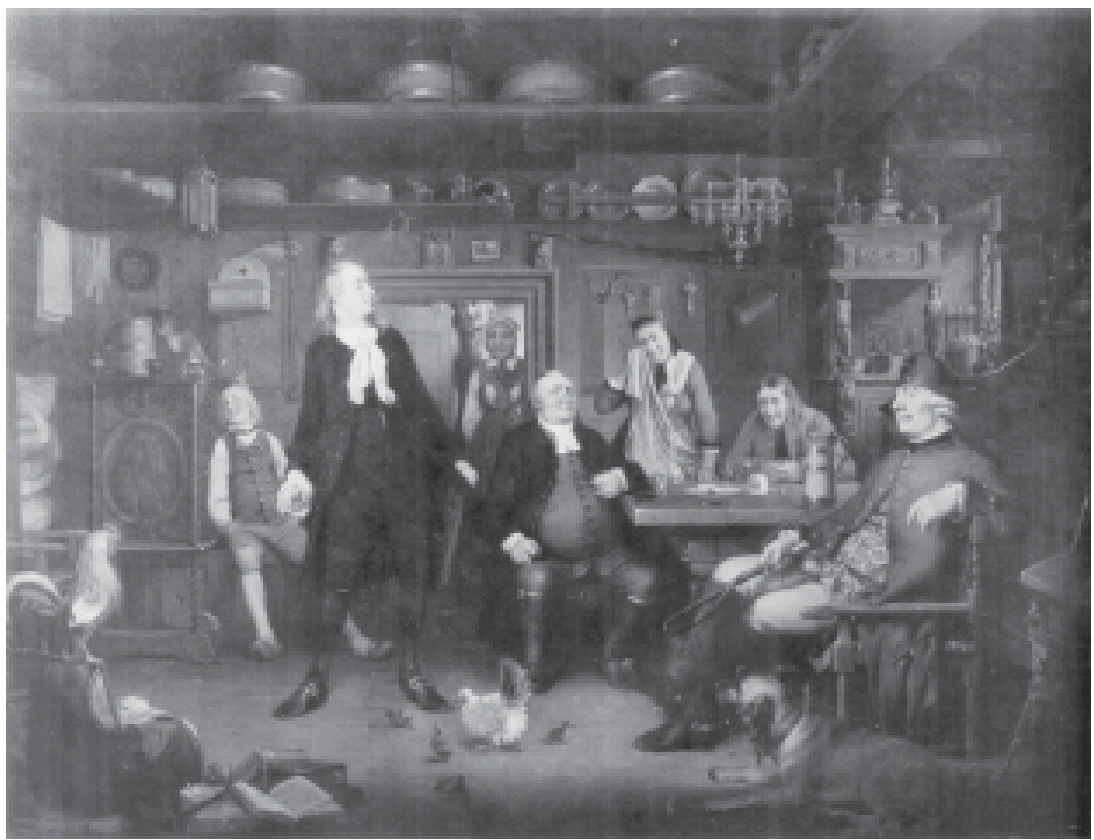

Vilh. Marstrand: Erasmus Montanus. Maleri, 1844. Statens Museum for Kunst.

Marstrandtiden, og med Holberg - bl.a. i syntetiserende lasninger; en af hans samlede Holberglasninger lagges frem i bogen Holbergs Billedbog fra 1922, som er en bog om Holbergs billedunivers og om Holberg og Marstrand; endelig er det af betydning, at bacchanalet, noert beslagtet som det er med saturnalie- og maskerademotivet, har hans sarlige bevågenhed, således $i$ hans Bacchustoget $i$ Norden fra 1904.

Vilhelm Andersen fremhaver i Holbergs Billedbog Holbergs plasticitet, hans humor og rundhed, som sarlige nordiske trak, $i$ modsatning til den sydlandske kфlige intellektualisme. Allerede i indledningen hedder det i en samlasning af H.C. Andersens eventyr og »Holbergs Billedbog «, altså inklusive Marstrands illustrationer, at: »Til falles har de et Prag af nordisk eller »gothisk « Aand, der volder, at man hos dem finder hvad man forgaves leder efter hos Lafontaine og Molière «. ${ }^{36}$ Hertil hører en sarligt folkelig tone og vinkel 
hos Holberg, en egen inderlighed og hjertelighed, ${ }^{37}$ som er humorens kendemarke. Der er her klare ekkoer af en sarlig grundtvigsk nord-syd antago-

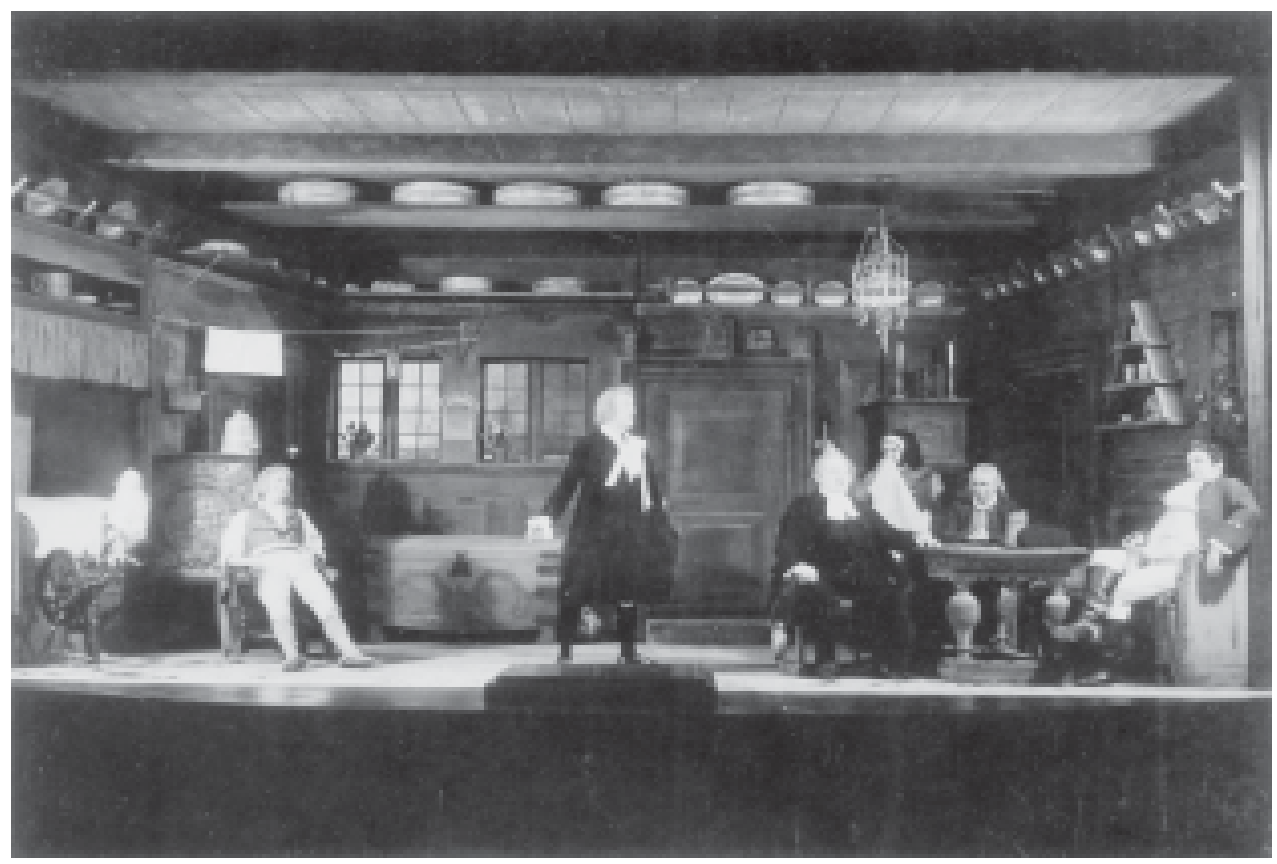

Erasmus Montanus. Det kgl. Teater, 1939.

nisme. ${ }^{38}$ Vilhelm Andersen bliver selv en intuitiv billedmager, som når han fremhaver, at Holbergs politiske kandestфber »Mester Herman er tyk og rund, varm i Kфdet og med en Lugt af sit Haandvark... «. Der står ikke et ord om Hermans udseende hos Holberg, men skildringen svarer til Marstrand og til fremstilleren af rollen fra $1907 i$ William Blochs naturalistiske opsatning, den af Andersen hojt beundrede Olaf Poulsen. ${ }^{39}$

Det folkelige og nationale er centralt. Komedier som Den Stundeslose, Barselstuen, Juele-Stue, Mascarade og Kilde-Reysen har »Bund i nationale Skikke og folkelige Lege, som Molières Komedier savner ${ }^{40}$ Andersen underspiller Holbergs kritik af den pra-urbane folkelighed, som han så som farlig irrationalitet, men romantikerne sidenhen fremhavede som uvurderlige »folkeminder «. Det nationale er billeddannelsens grundstof, som når det om JueleStue hedder at, den »foregår »i Ebeltoft «, men naar Holberg siger Abeltoft, mener han Bergen ... eller Christianssand. »Provinsen« var for Holberg Norge, kun »Landet « var Sjalland. Kampen mellem det gamle og det nye, der er Sjalen i saa mange af Holbergs Komedier, kunde aldrig blive en blot »Idé« for ham, det var hans Billedbog fra Barndommen $*{ }^{41}$ Denne kamp mellem 
gammelt og nyt er central $i$ Andersens og Nielsens opera. Om oprettelsen af et komediehus i 1722 skriver Andersen, at den kunstneriske realisme alene havde hjemlige forudsatninger: »det norske Anlag for Karikatur, den danske Sans for Karakteristik, det sekstende Aarhundredes Trasnit, og det syttendes Genrebilleder. Anledningen til den danske Skueplads var den franske Skuespiller Montaigus Privilegium, men Aarsagen dertil laa i Folket selv og $i$ Kobenhavnernes Komediehum $\phi$ « $^{42}$ - hvor man så kan spфrge sig, hvordan det gik til, at teatret idelig måtte kampe på randen af ruinen på grund af slet publikumssøgning; og bl.a. derfor måtte satse på maskerader som indtogtskilde.

Det er som antydet $i$ h $\phi j$ grad Holberg som billedmager, Andersen forf $\phi l$ ger, med »hollandsk« som grundpradikat - Don Ranudo forklares at forholde sig »til de andre i den hollandske Stil som Velasquez, til Jan Steen ${ }^{43}{ }^{43}$ Andersen fremkalder de billeder, Holberg angiveligt har set for sit indre фje, ser dem $i$ billedkunsten realiseret af Vilhelm Marstrand og relaterer dem i $\phi v$ rigt til William Blochs iscenesattelser. ${ }^{44}$

Progressionen er altså denne: Marstrands visuelle Holberg-lasning er bl.a. $i$ sit udgangspunkt grundtvigsk influeret og bliver eksemplarisk udgangspunkt

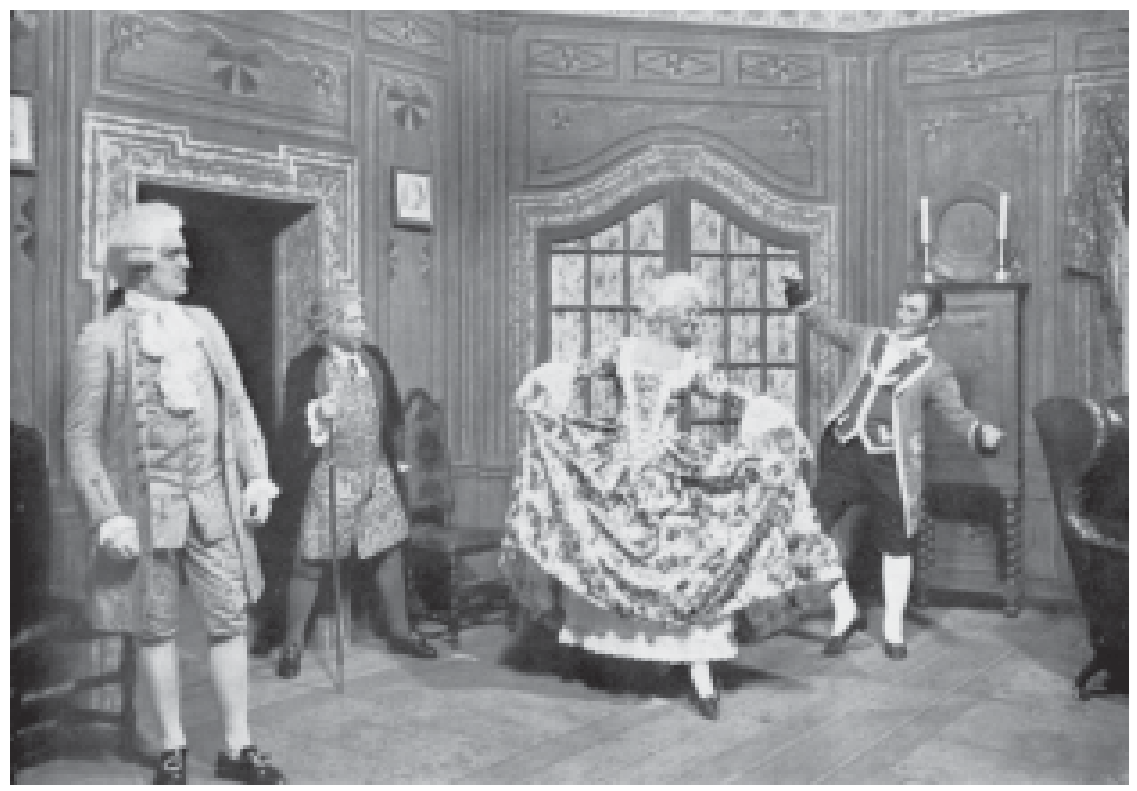

Maskerade (opera) 1.akt, hos Jeronimus. Det kgl. Teater, 1906.

for først de historistisk-realistiske, siden de naturalistiske opsatninger, som hos en William Bloch fär model-karakter. Vilhelm Andersens udgangspunkt 


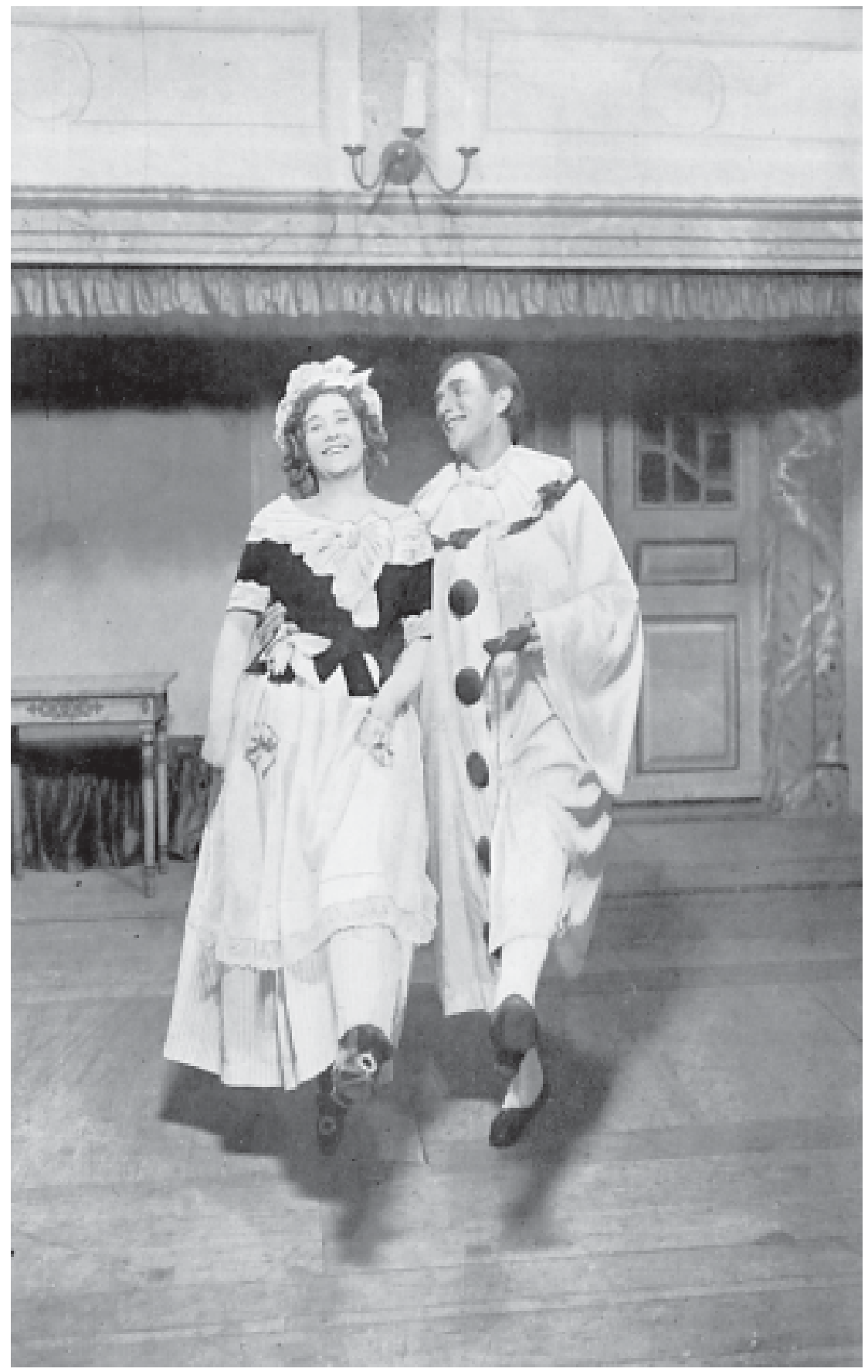

Maskerade (opera) 3. akt, i dansesalen. Det kgl. Teater 1906. 
er beslagtet med Marstrands, og påstanden er altså, at det farver forst hans littercere Holberglasning, siden hans artistiske i operaen.

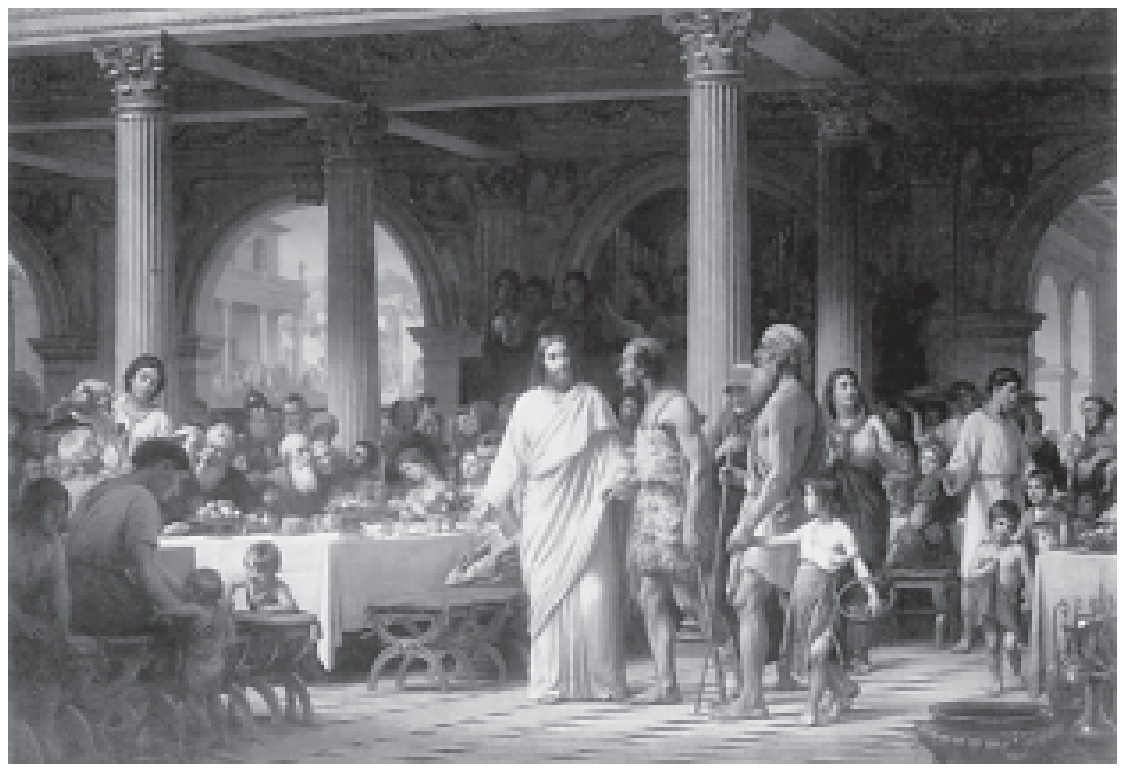

Vilh. Marstrand: Den store Nadver. Maleri, 1869. Statens Museum for Kunst.

Marstrand maler 1869 billedet af Den store Nadver, Jesu gastebud, som Andersen analyserer $i$ Holbergs Billedbog. Kunst er ikke bare ironi og humor, siger han her, ikke blot sandhed og retfardighed, men også karlighed. ${ }^{45}$ Holberg er inde i billedet: »Ogsaa Jeppe er med. Han sidder ved Bordet yderst til venstre med sфlvhvidt Haar i en gyldengul Kaabe, og ingen Jacob Skomager, men en Engel i menneskelig Skikkelse skanker for ham«, mens den himmelske musik klinger. „Det er jo Jeppes Drøm, som det var Aladdins ... Maaske det ogsaa var eller blev Holbergs«. Det er i hvert fald nok Vilhelm Andersens drøm, at det var Holbergs drøm, han minder om komponisten Johann Adolph Scheibes beretning om Holbergs grebethed ved kirkemusik ved en bestemt lejlighed; der lyser ud af teksten et håb om eksistensen af en dyb religiфs folelse hos Holberg, en syntese af Holberg og Grundtvig. Vi er under alle omstandigheder ganske langt fra det Holbergske bacchanal: de afsindige guder der skaber mennesket i fuldskab. Slutordene i Holbergs Billedbog siger bl.a.: »Man kommer til at holde endnu mere af Holberg, naar man ser ham med Marstrands Øjne ... [Holberg] drev aldrig Spot med dem, der havde Aand og Hjerte. Holbergs Komedier er som Marstrands Billeder en Fest. Men 
de er som den Hфjtid, alle Nordboer elsker mest, en Fest for Lyset og i Mфrket ${ }^{46}{ }^{4}$ Hvad det er for et begreb om fest skal vi herefter se på.

Den universelle livsfylde, som beskrives i Bacchustoget i Norden (skrevet 1903, året for librettoen til Maskerade), er sat op på rusens kreative ladethed, det dionysiske, kunsten i en religiфs dimension, bacchanalets sakramente så at sige - i Norden med et sarligt forgangelighedstema, en dødsbevidsthed, som givetvis reflekteres i Marstrandsbogens slutord: »... en Fest for Lyset og $i$ Mфrket«. Det dionysiske udfolder sig i Norden paradigmatisk med Holbergs Jeppe, laest ind $i$ et meget vidt perspektiv:

»Jeppe er den nordiske Kunsts første og fuldkommen originale Sidestykke til Michel Angelos Bacchus. Det er unagtelig en anden Stil, men det er endnu en Statue-Stil ... Og denne Statue er det forste Menneskebillede i den nordiske Kunst. Man plejer at sige, at Rencessancen først »opdagede Mennesket «. I det Bacchustog til Barbarerne, som man kalder »Rencessance«, udfoldede sig paa ny det oprindelige Hedenskab, den uvilkaarlige Blomstring af Menneskenaturen, der havde lukket sig sammen af Angst i den middelalderlige Kristendom. Her $i$ Norden er det da den holbergske Komedie, vort eneste Renassancevark, der gфr denne Opdagelse, og iscer Jeppe. Og hertil har som i Syden Dionysos givet sin Bistand. Jeppe er et Dyr, som, loftet af Rusen, udlader alle Menneskenaturens oprindelige Krafter ... Som man husker bliver Jeppe to Gange beruset ... Forst under denne dobbelte Ild aabenbarer han alt, hvad han indeholder. Men under denne dobbelte Ildprфve f $\phi$ dtes netop den frodige og ubandige Menneskerace, man kalder »Renassancemennesket $\ll$ her $i$ Norden ${ }^{4} .{ }^{47}$

Dette billede af rusens universelt forlфsende kraft, festen som livets og karlighedens kerne og kilde, bacchanalet som sakramente - jf. Andersens tale om, at »den moderne Dionysos er her som overalt Kunsten, der er ved at blive Religion «, ${ }^{48}$ og jf. lignelsen om Den store Nadver - dette billede spiller med $i$ udlagningen af maskerademotivet $i$ Vilhelm Andersens libretto til Maskerade. Som når det i Henriks arie »Vifødes i Armod, vi svфbes $i$ Sult «, $i$ vers 3 og 4 hedder:

»Da hvirvler det brogede Masketog, med Frihed og Lighed af Sted, med den rigeste Drot og det fattigste Drog hvad Under, om vi vil med? 
$\mathrm{Du}$, som fryser derude kom ind og vaer Gast!

Her er glemsel for $N \phi d$ og Fortrad.

$A k$, kunde jeg køre Alverden paa Fest

og ta Kusken og Hestene med! «9

Henriks defensorat er i operaen flyttet til første akt, fra Holbergs II. akt, sc. 3, og de citerede vers udhaves $i$ et markant skift i musikken. Forlagget $i$ Holbergs tekst lyder: »... Jeg ville фnske vi kunde tage Kudsken og Hestene med ind paa Mascaraden, at de stakkels Beester ogsaa kunde have nogen Tiidsfordriv og nogle gode Timer blant saa mange sure Dage«, altså en robust vittighed, som slår kusk og heste i hartkorn som »Beester «, ingen antydning af det billede som hos Andersen uvagerligt genkalder den marstrandske vision af Den store Nadver: »Du som fryser derude, kom ind og vaer Gast « har klare Jesus-genklange, og da iscer netop fra Lukas 14. kapitel, vers 15-24, lignelsen om de fattige og udstodte som bydes ind til det store gastebud (samt Matth. 11,28 om de tratte som inviteres til Frelseren). ${ }^{50}$ I selve maskerade-akten forekommer en rakke henvisninger til Bacchustoget i Norden, fra Broder Rus til Jeronimus kostumeret som Bacchus. Om sammenhangen mellem Bacchustoget $i$ Norden og Maskerade kan i $\phi v r i g t$ henvises til analysen i Jorgen I. Jensens Carl Nielsen-bog. Der er ikke meget at føje til den fremstilling - bortset fra måske, at Jensen gør en pointe ud af, at operaens tredieakt synligg $\phi r$ maskeradens univers, til forskel fra komedien, hvor den kun figurerer som symbol i omtale. ${ }^{51}$ Det er faktisk ikke rigtigt; Holberg giver omhyggeligt anvisning på, at maskeraden, herunder Leanders og Leonoras møde, skal opføres på scenen. "Naar samme Presentation har varet et Quarteer, lader man Dakket falde", slutter han af. Et kvarter er temmelig lange på teatret.

Vilhelm Andersen har $i$ en artikel fra 1906 beskrevet Henrich-figuren $i$ Holbergs Mascarade som »Uroen i Samfundet der er ved at falde $i$ Staver af lutter Arbarhed «, han er musikalsk, »Den nordiske Litteraturs første Kunstner", og Carl Nielsen har siden udtalt, at der er noget revolutionart ved Henrich - »han siger ligefrem socialistiske Ting «. ${ }^{52}$ Jeg mener, der langt hen er tale om projektioner og indlasninger. Henrich som kunstneren er imidlertid ganske pracist. Dog mener jeg ikke, musikken er hans element (som det selvklart er tilfaldet $i$ Andersens Henrik) - men teatret: han fardes hjemmevant $i$ fiktiviteten, utvungent improviserende, da han netop ikke er bundet af illusion om konstans og sammenhang.

Fra maskeraden som relativitetens univers er den hos Andersen rykket over til at bare livsfyldens gladelige budskab, konkret haftet op på en lasning af det 18. århundrede som frihedens, kunstens, musikkens tid, scenisk-visuelt materialiseret $i$ anden akt $i$ det gamle fadrene hus over for det nye komedieog maskeradehus; Leander synger til de to huse: 
»Se, Henrik! hvor Nat og Mфrke knuger

den gamle Gaard, hvor mine Fadre gik

til Morgenbøn og Aften-Sang og -Drik!

Se, hvor de sorte Skodder Sфvnen suger.

Vend dig saa om og se, med aabne Luger

det nye Hus med Glans i sine Blik!

Hor, hvor dets Vagge toner af Musik!

Se, Lyset valder ud af alle Fuger!

Sov trygt, du gamle Gaard, sov sфdt og rolig,

Luk for vor Tid kun dine Øjne til, du gamle Saculum, du Søvnens Bolig!

Hil dig, du nye Hus, hvor Folk forundred'

slog Øjet op til Fest, til Skuespil

du klare frie attende Aarhundred,

Dig valger jeg, thi dig jeg horer til.

Dig valger vi, thi dig vi horer til. $«^{53}$

Som det vil vare fremgået af den historiske gennemgang, er det en romantiserende projektion: komediehuset var ingen succes, aktфrerne var ganske bastant forfulgt fra Universitetets side for den dubiøse profession, de bedrev, en forfølgelse, som tilmed blev genoptaget 1748 i relation til det genoprettede komediehus, maskerader på komediehuset forblev forbudt indtil 14 år efter Holbergs d $\phi$ d... Ikke at der er noget diskutabelt i opera-operationen: $i$ kunst og karlighed gaelder alle kneb! Men den Holberglasning, Vilhelm Andersen lagger til grund, og som altså er analytisk, ikke kunstnerisk, peger i retning af, at han rent faktisk mener at forlфse den »sande "Holberg. Den lasning er ganske stark, bl.a. på teatret, og kan i polemisk forkortning beskrives som en humaniserende nostalgisering. Dette er altså ikke blot, endsige primart, en diskussion med en d $\phi d$ forsker, men tillige med en levende tradition.

Jeg mener, disse betragtninger bekraftes af argumentationen i den bastante afvisning fra 1923 af Harald Nielsens Holberg-disputats, et vark, som isar netop baseres på en indlasning af de sorte skamtedigte i komedierne. Den klare afvisning, som er forfattet af Vilhelm Andersen, siger bl.a., at »Det klassiske i Komedien (: Jeppe paa Bierget) ikke ligger $i$... Ideen ... men som hidtil antaget $i$ det psykologiske" - hvorved man altså får en lasning af Jeppe paa Bierget som citeret fra Bacchustoget i Norden, stik imod forfatterens er- 


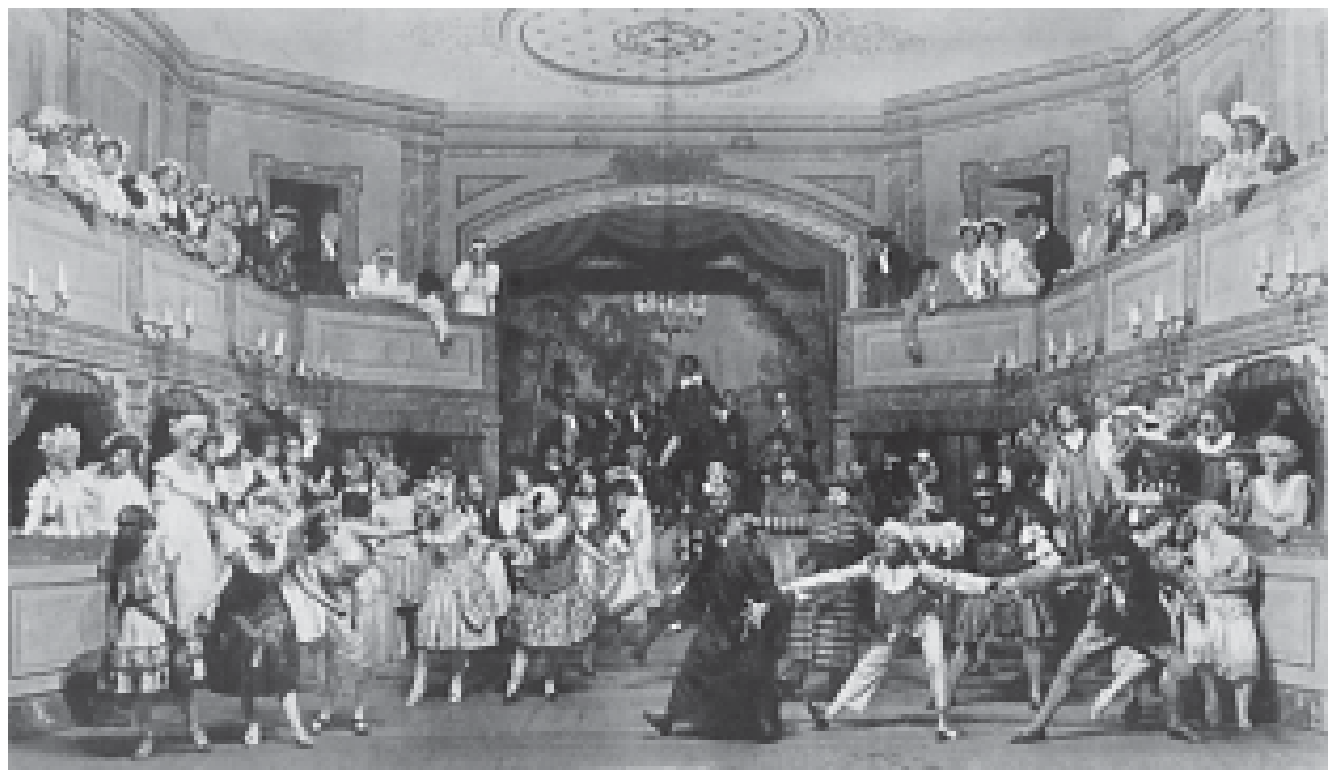

Mascarade (komedie, med genbrug fra operaen), intermediet, dansesalen. Det kgl. Teater, 1914.

klarede hensigt; og videre at »Forfatteren ved at sфge det konstante eller klassiske i Holbergs Menneskeopfattelse i det forste af hans Fire Skamtedigte med det satirisk-pessimistiske Syn paa Livet (Mennesket er et farligt og ynkvardigt Dyr) i Stedet for det andet med det kunstnerisk-humoristiske Syn (Mennesket er et Dyr, som man ikke kan definere) har fortolket Holberg udfra en Synsmaade, som Holberg selv, da han skrev dem, havde afvist «. ${ }^{54}$ Andersens lasning af andet skamtedigt, om den ustadige Tigellius, er yderst diskutabel; det centrale er imidlertid, at Holberg partout skal vare enten-eller, og dog er både-og, komplementar, og derfor klassiker og ekstremt scenisk, dvs. dialektisk-dialogisk i forhold til sit publikum. Det »kunstnerisk-humoristiske«, som Harald Nielsen problematiserer, er jo det dionysisk-karlige, bacchanalet, Den store Nadver. Er det Andersens kronjuveler, Nielsen er inde at pille ved?

Der er altså tale om, at et egentligt litteratur/kunstvidenskabeligt vark afsatter sig tematisk-kunstnerisk i librettoen, som i høj grad kommer til at forme musikken. ${ }^{55}$ Den nydelsesfulde gammelk $\phi$ benhavnske fortrolighed, som gennemsyrer operaen - herunder iscer librettoen og opsatningskonventionen - er overtaget fra naturalismens Holberg ${ }^{56}$ med model og inspiration i Marstrand, den forsonlige humor, ikke den illusionsl $\phi$ se komik. Med denne insisteren på gladesfesten/bacchanalet, den ensidige tagen parti for ungdom og letsind med tilhфrende kontant latterligg $\phi$ relse af forcldregenerationen, bliver der ikke meget tilbage af Holbergs kompleksitet, det grundlaggende kaos disciplineres $i$ karligt humoristisk retning. Hvor Le Coffres maleri mytologiserer en realitet, og Holbergs komedie i kraft af sin ekstremt intime bundethed til en omgivende virkelighed gor det samme i en uendelig mangetydighed, da forekommer det mig, at der i operaen er tale om en mytologisering af et bestemt 
lyst Holbergsyn og en teatertradition, den naturalistiske; at der for så vidt ikke er nogen spanding mellem varkets ydre realitet (som altså udgфres af teaterbilleder) og dets indre univers, at de tvartimod stemmer perfekt overens.

At operaen Maskerade som tekst- og musikvark ikke nфdvendigvis kun hanger sammen med denne national-museale ballast, som prager dens position i Danmark, ${ }^{57}$ fremgår måske af den karriere, den i disse år er ved at gфre $i$ Tyskland, altså $i$ en sammenhang, som er lфsrevet fra en sarligt folelsesengageret tradition og placeret $i$ en radikalt anderledes kontekst. Det hedder i en anmeldelse fra af en opsatning i Stralsund i foråret 1997 bl.a.: »Kobenhavns topografi har fået Schwamm darüber, Leanders serenade til gadens gamle hus synges til en lille håndholdt bymodel, mens et kimarefyldt virvar tårner sig over ham med akvaduktagtige lфbebroer. Basilisker og enhjфrninger dvaler på afsatserne, stormomsuste bagtcepper med karaveller sanker sig i baggrunden, og et opspilet helvedesgab danner elevator for de feststemte maskeradegaster. I en så drastisk allegorisk tolkning viser det sig, hvor megen fremragende teatermusik, Maskerade rummer, langt slidstarkere end den substanssvage operasmagten, der falder tilbage på den danske nynnen. Det virker som om Nino Rotas isluft fra Fellinis Casanova blaser gennem Maskerade... ${ }^{58}$

\section{Noter}

1. Om datering m.v. se Chr. Elling: "De dekorative Malerier paa Frederiksberg Slot» i Frederik Weilbach (red.): Frederiksberg Slot, Kbh. 1936, p. 88ff. Ofte peges på 1704 som tilblivelsesåret. Der er i maleriet bemarkelsesvardige overensstemmelser med såvel Giambattista Tiepolo som Watteau, der maler flere år senere! Det kan hange sammen med Le Coffres lareår i Paris, hvor en form for pra-rokoko gjorde sig gaeldende blandt Antoine Coypel, Charles de la Fosse m.fl., jf. Birgitte Bøggild og Hugo Johannsen: Kongens kunst (:Ny dansk kunsthistorie, II), Kbh. 1993, p. 220.

2. Louis Bobé: Bogen om Frederiksberg Slot, Kbh. 1922, p. 62. I så fald er cembalospilleren nederst til højre Paul Chr. Schindler, forfatteren til Der vereinigte Götterstreit, hofoperaen, som i 1689 havde voldt den katastrofale teaterbrand, se Bent Holm: »Fra pomp til paedagogik«i Kela Kvam et al. (red.): Dansk teaterhistorie, I, Kbh. 1992, p. 59ff.

3. Bircherods dagbog efter Erich Chr. Werlauff: Historiske Antegnelser til Ludvig Holbergs atten forste Lystspil, Kbh. 1858, p. 215.

4. Som i Palladius' ord i 1556 om fastelavnsdjavelen, som han havde pradiket imod $i$ tyve år og som nu endelig var »bortjaget, så at vi have siden haft fred for hannem, des vare Gud lovet", citeret efter Dansk litteraturhistorie, II, Kbh. 1984, p. 214.

5. Nyt Archiv for Psychologi, Historie etc., 11, Kbh. 1829, p. 113ff.

6. Se Bent Holm: " De talte om Comoedi-Spil som Dievlens Strik og Snare'. Teater og teologi under pietismen « $i$ Fønix, 14. årg., 2, Kbh. 1990, p. 111 om bl.a. Caspar Brochmand. 
7. Werlauff, p. $196 f f$ og p. 217 (se note 3).

8. Op. cit., p. 198.

9. Bevilling af 12.5.1721, jf. op. cit., p. $220 f$ og Eiler Nystrøm: Den danske Komedies Oprindelse, Kbh. 1918, p. 71f, som taler om ugentlige assembleer for hoffolk, kavallerer og ellers hvem der vil og må, blot alt går sфmmeligt for sig. En perspektivering af kombinationen af forlystelser giver Chr. Elling: Operahus og Casino, Kbh. 1942; det skal herudover navnes, at Joh. C. v. Eckenberg, »Den stcerke Mand « kaldet, som en tid opererede $i$ Kobenhavn, $i$ 1730erne fik en position i Berlin dels som kgl. hofkomediant, dels som »Unternehmer der Assembleen, die in dem Fürstenhause wöchentlich zweimal stattfinden «, jf. Werlauff, $p$. 223. Privilegiet dakkede nogenlunde de samme områder som det tilsvarende københavnske.

10. Werlauff, p. 235 f om privilegiet. Conseil-beslutning jf. Harald Langberg: Kongens teater. Komediehuset på Kongens Nytorv 1748-1774, Kbh. 1974, p. 73 og p. 96.

11. Inventarfortegnelsen gengivet i Torben Krogh: Studier over Harlekinaden paa den danske Skueplads, Kbh. 1931, p. 48.

12. I Epistel 374 taler han om »at forestille de forrige Tiders Overtro og Simplicitet udi Festens Helligholdelse" som hensigten med komedien. I Epistel 226 kalder Holberg julestuer »christelige Saturnalia« og foretager altså en hedensk javnføring. Epistlen bygger muligvis på indtryk fra helligdagsforordningen af 1730; Holberg beklager, hvis »Socialitet, som er Sielen udi en Stad, ophфrer; Misanthropie og Tungsindighed befordres... " og røber vel altså dog sympati for det robuste samvar, omend formen er det ironiske paradoks. I Juele-Stue, sc. 12, er argumentet for festens afholdelse skolemesterens henvisning til Aristoteles' begreb on »zoon politikon, id est: homo est animal sociabile«, som også indgår i Holbergs menneskesyn. Et interessant supplement til Epistel 226 er Kristen Sфrensen Testrups optegnelser fra 1740 fra Rinds Herred, hvori han beklager, at »Folks Humør og Lystighed « $i$ bl.a. julelege, sømmelige såvel som mindre sфmmelige, er nu »saa ganske aflagt«, se Samlinger til jydsk Historie og Topografi, II, Aalborg 1868-69, p. 72. Alle Holberg-henvisninger refererer til Carl S. Petersens udg. af Samlede Skrifter, I-XVIII, Kbh. 1913-63.

13. Peter Burke: Popular Culture in Early Modern Europe, London 1978, p. $60 f$.

14. Hans Brix: Ludvig Holbergs Komedier, Kbh. 1942, p. 286: Holberg »har afleveret sit Manuskript omtrent paa Dato for Afslutningen af det Capion'ske Karneval, lige f $\phi r$ Fasten. Som Finale paa Festen fulgte de tre Opførelser af »Mascarade«, hvoraf den sidste faldt paa selve Fastelavns-Mandag...«. Blandt en rakke dokumentariske trcek kan fremhaves III,9: „Jeg har alt haft Bud i Dag til Capion. Der blir ingen Mascarade i Aften ". Capion var som navnt bevillingshaveren i huset, maskeradearrangфren. I II,4 refereres til »Ane Hattemagers Bataillon«. Ane var en faktisk eksisterende, berygtet bordelmutter, som 1723 blev kagstrøget og stod $i$ halsjern på Nytorv, jf. Werlauff, p. $246 f$ (se note 3). Henriks forhold til luderne, professionelle spillere på deres felt som de er, er ganske organisk. Holbergs syn på prostituerede var såre pragmatisk, som når han i sin natur- og folkeret, 1716, $i$ kapitlet om $\phi v$ vighedens ret bemarker, »at Venedig engang fordrev alle Skiфger, men siden maatte forskrive hele Skibsladninger igien «. For Jeronimus derimod rangerer maskeraden I,7 på linje med »Horehuus «. Da komedien kom op igen 1747 efter den teaterl $\phi s e$ tid, på interimscenen i Bergs Hus, var det atter et blandet og blakket etablissement, der dannede rammen, på et tidspunkt omtalt som »Hoerhuus«, jf. Bent Holm: »De talte om Comoedi-Spil« (se note 6), p. 106f. 
15. Således Leonards to timers middagss $\phi v n$, som muliggg $\phi r$ hyrdetimen III,1. Men man er ikke sikker på, om han $i$ sin ophidselse kan sove, og i sc. 3 dukker han da også ubelejligt op...

16. Erik A. Nielsen: Holbergs komik, Kbh. 1984, p. $236 f f$.

17. I kapitlet »Om Naturens Lov«. De følgende citater er fra kapitlerne »Om Agteskab og »Om Foraldrenes og Børnenes Pligt«.

18. Jf. Kåre Foss: Ludvig Holbergs naturrett, Oslo 1934, p. $410 f$; i 1734 udg. indføjedes $i$ slutningen af kapitlet om forceldres og børns pligt, at barnet tilsyneladende kan vagre sig ved en aegtefalle, hvis dets sind ikke er dertil, da agteskabets bånd bør vare karlighed og det er svart at elske efter ordre.

19. Jf. Hans Brix: Ludvig Holbergs Komedier, p.288f, som opstiller Regnards Dobleren som mulig model. Heri er den unge mand ved at фdelagge sin eksistens ved sin spillelidenskab.

20. Se fremstillingen heraf hos Foss (se note 18). I varket annonceres flere steder, at Foss ville gå videre med at applicere sine resultater på egentlige tekstlasninger. Desvarre blev projektet ikke gennemfort. Edvard Holm har ligeledes fremlagt Holbergs statsretslige synsmåder, jf. Ludvig Holbergs statsretlige og politiske Synsmaade, Kbh. 1879. Den dobbelthed, han registrerer, er markeligt overset; se fx op. cit., p. 64: »Jo mere Holberg paa mange Punkter har fastholdt Statsmagtens Ret og Kald til at regulere alt, jo mere han i andre Henseender har vist Mistillid til den frie Rorelse, desto starkere bliver man slaaet af at se ham paa saa vigtige Omraader krave Frihedens Ret uden at han andser, hvorledes han derved banede Vej for en Kritik, der let kunde komme til at vende sig mod den enevaldige Kongemagt«. Om magttemaet se også Bent Holm: »Kongen og narren. Symbol, teatralitet, spektakularitet i barokkens teater $i K \& K 73$ (1993).

21. Jf. Torben Krogh: Holberg i Det kongelige Teaters aldste Regiejournaler, Kbh. 1943, p. 46. Det var, hvad han havde på til maskeraden; de unge derimod hvide dominoer, uskyldens farve. Dette er senere, men måske konvention.

22. Sml. Apelone i Hexerie eller Blind Allarm, IV,1: »... det er en Hazard ved at forlove sig med en Acteur, som er vant til hver Aften at giøre ny Elskov og gifte sig saa tit, som en Autor behager at giфre mange Comoedier til«.

23. Gengangeren, som viser sig ved karnevalstide og bringer sandheden for en dag, peger hen på karnevallet som et (hedensk) lag under maskeraden, som Henrich reprasenterer - inklusive de dybere lag.

24. Således I, 4; beklagelserne over gadernes urenhed og uviljen ved at gå til fods genfindes i Epistel 189. Hans anti-sentimentale syn på »Tragoedier og Romaner«, III, 4, er ganske holbergsk, som i det hele taget hans nytte- og arbejdssomhedsmoral.

25. Set i sammenhang med Juele-Stue er det interessant, at Henrich hedder Abbeltoft til efternavn, og altså reprasenterer festens oprindelige vanvid. At Arv til gengald er fra Chr. Bernikowsstrade tegner et bovlamt billede af den gammeldags hovedstad, Jeronimus' univers.

26. Jf. Hans Brix: Analyser og Problemer, V, Kbh. 1940, p. $202 f$.

27. Sml. bevagelsen fra Tigellius-satirens afbildning af ubestandighedens konstans til komedien om Den Vagelsindede, som forskyder accenten fra grundvilkår til karakterbrist.

28. Chr. H. Amthor: De jure decori, Kbh. 1728; relevante passager p. 173ff. Amthor er langthen moderat som en hr. Leonard. Det er excessen, der er diskutabel. Mod maskeraden er han dog absolut kritisk.

29. Erik Pontoppidan: Fejekost til at udfeje den gamle Surdejg eller de i de danske 
Lande tiloversblevne og her for Dagen bragte Levninger af saavel Hedenskab som Papisme (:Danmarks Folkeminder, 27, v. Jørgen Olrik), Kbh. 1923 (org. Everriculum fermenti veteris, Kbh. 1736), p. 28ff.

30. Egid. Günth. Hellmund: Teologiske Svar paa de to Spфrsmaale: I. Om Dantz, som nu omstunder фves saa meget $i$ Verden, er Synd? II. Om Spill er Synd?, Kbh. 1740, p. 31 .

31. Erik Pontoppidan: Neue Erörterung der alten Frage: Ob Tantzen Sünde sey? 1740, p. 21ff. Da Holberg 1751 skrev sin Tartuffe, sit portrat af en en pietist med henvisning til Zinzendorff-retningen, Philosophus udi egen Indbildning, kaldte han sin hovedperson Cosmoligorius, »verdenshaderen« - sml. Pontoppidans »verdenselsker« - der dog blot er døbt Cosmus Holgersen; der er i stykket formuleringer, der ligger forbløffende tat op ad Pontoppidan. Jf. også Bent Holm: »De talte om Comoedi-Spil«, p. $109 f$ (se note 6).

32. Jf. note 2.

33. Jf. også Kaare Foss, p. 372 (se note 18), om bl.a. Pufendorffs fremstilling af urtilstanden.

34. Tilsvarende er maskeraden som metafor ganske futil: den er futiliteten selv, usentimental seksualitet, drøm etc. etc.

35. I Prometheus, 2, Kbh. 1833, p. 174ff.

36. Vilhelm Andersen: Holbergs Billedbog, Kbh. 1922, p. 9.

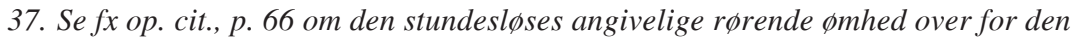
lille sorte høne.

38. Den er pudsig sammenlignet med Erik A. Nielsens grundtvigsk farvede refleksioner om »lys uden varme" hos Holberg, op. cit., p. 392ff (se note 16).

39. Beskrivelsen af mester Herman står $i$ Vilhelm Andersen: Holbergs Billedbog, p. 47. Olaf Poulsen var Blochs, og sin tids, forende Holberg-skuespiller. Andersen havde optrådt med Holberg-oplasninger sammen med Poulsen. I Vilhelm Østergaard (red.): Olaf Poulsen, Kbh. 1917, giver Andersen en karakteristik af Poulsens kunst, fx p. 100, p. 112 og p. 120, der kredser om »Rencessance«, »hollandsk « og det nationale/københavnske, plus-pradikater, der genfindes $i$ hans analyser af Holberg og Marstrand. 1926 blev Andersen i фvrigt gift med en datter af Olaf Poulsen.

40. Vilhelm Andersen: Holbergs Billedbog, p. 48.

41. Op. cit., p. 60.

42. Op. cit., p. 22. Sml. også det norske felttog: Holberg er alt dansk-fransk-tysks antipode og martyr, ridder for den sande, dvs. engelske, norskhed, ifx Viljam Olsvig: Holberg og England, Kristiania 1913.

43. Vilhelm Andersen: Holbergs Billedbog, p. 54.

44. Op. cit., p. 50.

45. Op. cit., p. $130 f$.

46. Op. cit., p. $131 f$.

47. Vilhelm Andersen: Bacchustoget i Norden, Kbh. 1904, p. 65, her citeret fra udg. 1956. Det bemarkes, at Jeppe er billedet på en unyttig, uproduktiv samfundsborger, hengiven til druk og fantasterier som han er, hvorfor han da også trakkes gennem intrigens padagogisk afrettende maskine, som de andre narre der straffes for kapitalsynden: virkelighedstabet. Hernost uddrager baronen moralen, at slippes irrationaliten lфs, slippes kaos fri er det universelle blodbad konsekvensen. At Holberg samtidig tegner en klassisk narrefigur, som $i$ kraft af identifikationseffekten $i$ høj grad slår benene vak under moralen, gфr blot kompleksiteten uopslidelig. Se også Bent Holm: »Ludvig Holberg and his Double« i Sven H. Rossel (ed.): Ludvig 
Holberg. A European Writer, Amsterdam-Atlanta 1994.

48. Vilhelm Andersen: Bacchustoget i Norden, p. 296.

49. Vilhelm Andersen: Maskerade, Kbh. 1928, p. 14f. Det er klart at friheds- og lighedstemaerne er inspireret af Holbergs Epistel 347.

50. Det er karakteristisk, at Leonards filosofiske maskeradeforsvar helt er udeladt; her er ingen uklarhed eller tvetydighed i tematikken og karaktertegningen.

51. Jorgen I. Jensen: Carl Nielsen - danskeren, Kbh. 1991, p. 236 og p. 250. Der peges på d $\phi d s-$ og forgangelighedstemaets narvar $i$ bacchanalet som det sarligt nordiske. Opfattelsen af maskeradens symbolbetydning forekommer at underst $\phi t t e$ Nadver-lasningen: bacchanalets sakramentale karakter, jf. op. cit. p. 249.

52. Vilhelm Andersen: »Holbergs Henrik«i Tilskueren, Kbh. 1906; her ligesom Carl Nielsen udtalelsen citeret fra Jorgen I. Jensen, p. $242 f$.

53. Vilhelm Andersen: Maskerade, p. 26. I Jørgen I. Jensens gengivelse er der et par tekstvarianter, bl. a. efter l. 10, hvor der står »du kan ej se den om du ogsaa vil«.

54. Aftrykt i Nina Bjфrneboe: Manden, der overlevede sin skaebne, Kbh. 1981, p. $298 f$. Sml. Harald Nielsen: Holberg i Nutidsbelysning, Kbh. 1923.

55. Jørgen I. Jensen, p. 236 (se note 51).

56. Operaen blev uropfфrt i en ny (naturalistisk) stuedekoration, med enkelte elementer fra den forrige opsatning af komedien, Emil Poulsens fra 1897; et gadesceneri med bl.a. en bindingsvarksgård fra den foregående sasons William Bloch-iscenesattelse af Hexerie eller Blind Allarm; og endelig en stort set nyproduceret dansesal. Kostumerne omfattede bl.a. Olaf Poulsens Henrich-liberi fra komedien, 1897. Da komedien igen kom op i 1914 blev maskeradesalen fra operaen overf $\phi r t$, jf. maskinmesterprotokoller m.v. i Det kgl. Teaters Arkiv og Bibliotek. Det sceniske univers var fortroligt, uden skelnen mellem Thisted og Kobenhavn, mellem opera og komedie - fallesnavneren var et på forhånd givet billede af Holberg.

57. I sason 1997-98 sattes operaen op på Det kgl. Teater i Ove-Chr. Petersens scenografi fra 1965.

58. Peter Johannes Erichsen $i$ Weekendavisen 18.4. 1997. 